\title{
Reviews and syntheses: Bacterial bioluminescence - ecology and impact in the biological carbon pump
}

\author{
Lisa Tanet $^{1}{ }^{\star}$, Séverine Martini ${ }^{1, \star}$, Laurie Casalot ${ }^{1}$, and Christian Tamburini ${ }^{1}$ \\ ${ }^{1}$ Aix Marseille Univ., Université de Toulon, CNRS, IRD, MIO UM 110, 13288 Marseille, France \\ ^ These authors contributed equally to this work.
}

Correspondence: Christian Tamburini (christian.tamburini@mio.osupytheas.fr)

Received: 21 February 2020 - Discussion started: 19 March 2020

Revised: 5 June 2020 - Accepted: 14 June 2020 - Published: 17 July 2020

\begin{abstract}
Around 30 species of marine bacteria can emit light, a critical characteristic in the oceanic environment is mostly deprived of sunlight. In this article, we first review current knowledge on bioluminescent bacteria symbiosis in light organs. Then, focusing on gut-associated bacteria, we highlight that recent works, based on omics methods, confirm previous claims about the prominence of bioluminescent bacterial species in fish guts. Such host-symbiont relationships are relatively well-established and represent important knowledge in the bioluminescence field. However, the consequences of bioluminescent bacteria continuously released from light organs and through the digestive tracts to the seawater have been barely taken into account at the ecological and biogeochemical level. For too long neglected, we propose considering the role of bioluminescent bacteria and reconsidering the biological carbon pump, taking into account the bioluminescence effect ("bioluminescence shunt hypothesis"). Indeed, it has been shown that marine snow and fecal pellets are often luminous due to microbial colonization, which makes them a visual target. These luminous particles seem preferentially consumed by organisms of higher trophic levels in comparison to nonluminous ones. As a consequence, the sinking rate of consumed particles could be either increased (due to repackaging) or reduced (due to sloppy feeding or coprophagy/coprorhexy), which can imply a major impact on global biological carbon fluxes. Finally, we propose a strategy, at a worldwide scale, relying on recently developed instrumentation and methodological tools to quantify the impact of bioluminescent bacteria in the biological carbon pump.
\end{abstract}

\section{Introduction}

Darkness constitutes the main feature of the ocean. Indeed, the dark ocean represents more than $94 \%$ of the Earth's habitable volume (Haddock et al., 2017). Moreover, the surface waters are also in dim light or darkness during nighttime. Organisms living in the dark ocean biome are disconnected from the planet's primary source of light. They must adapt to a continuous decrease in sunlight reaching total darkness beyond a few hundred meters. Hence, it is not surprising that $76 \%$ of marine pelagic meso- and macroorganisms are bioluminescent from the surface to the deep sea, without variability over depth, and that bioluminescence is a major ecological function in interactions (Martini and Haddock, 2017). Bioluminescent species are found in most phyla from fish to bacteria (Haddock et al., 2010; Widder, 2010). Amongst marine light-emitting organisms, luminous bacteria are widely distributed in oceans. Luminescent bacteria can glow continuously under specific growth conditions (Nealson and Hastings, 1979), while, in contrast, eukaryotic bioluminescent organisms require mechanical stimulation to emit light (Haddock et al., 2010). Most of the currently known bacterial luminous species (about 30) are heterotrophic, copiotrophic and facultatively anaerobic (Dunlap, 2014). Endowed with important motility and chemotactic abilities, luminous bacteria are able to colonize a large variety of habitats (as symbionts with macroorganisms, free-living in seawater or attached to particles) (e.g., Dunlap and Kita-tsukamoto, 2006, and references therein). In their symbiotic forms, bioluminescent bacteria are mostly known to colonize light organs and guts, in which they find better growing conditions than in the open ocean. These symbioses lead to a continuous release 
of luminous bacteria from light organs and digestive tracts, directly to the seawater or through fecal pellets (Ramesh et al., 1990). Bacterial bioluminescence in its free or attached forms is much less studied but is worth reconsidering, in its prevalence as well as its ecological implications. To our knowledge, no archaea has been characterized as bioluminescent.

The biological and physical (solubility) carbon pumps are the main drivers of the downward transfer of carbon and play a central role in the sequestration of carbon dioxide (Boyd et al., 2019; Buesseler and Lampitt, 2008; Dall'Olmo et al., 2016). The biological carbon pump is defined as the process through which photosynthetic organisms convert $\mathrm{CO}_{2}$ to organic carbon, as well as the export and fate of the organic carbon sinking from the surface layer to the dark ocean and its sediments by different pathways (Siegel et al., 2016, and references therein). Sinking particles (bigger than $0.5 \mathrm{~mm}$ of diameter) known as marine snow are a combination of phytodetritus, living and dead organisms, and fecal pellets (from zooplankton and fish). Marine snow, rich in carbon and nutrients, and its surrounding solute plumes are hot spots of microbial activity in aquatic systems (Alldredge et al., 1990; Alldredge and Silver, 1988; DeLong et al., 1993). Marine snow is also consumed by zooplankton, and fecal pellets are a food source through coprophagy. When leaving the epipelagic zone and sinking to depth, organic particles would be utilized by microbial decomposition and fish/zooplankton consumption, both considered to be responsible for a large part of the variation in the efficiency of the biological carbon pump (De La Rocha and Passow, 2007). Recently, fragmentation (potentially due to biological processes in the mesopelagic waters) has also been shown to be the primary process controlling the sequestration of sinking organic carbon, accounting for $49 \pm 22 \%$ of the observed flux loss (Briggs et al., 2020). Moreover, some studies pointed out the well-adapted vision of fish or crustacean to the detection of point-source bioluminescence (de Busserolles and Marshall, 2017; Frank et al., 2012; Warrant and Locket, 2004). The compiled data, from all forms of marine bacterial bioluminescence, presented and discussed in this review bring out the uninvestigated pathway of the bioluminescence contribution into the biological carbon pump, through the visual attraction of consumers for luminous particles.

In this review, we will summarize the current knowledge on bioluminescent bacteria based on former and recent literature. First, we describe symbiotic bioluminescent bacteria in light organs of fish or squid, its importance, and controls. Then, we present enteric-association occurrences. One of the consequences of these symbioses, in both light organs and guts, is a massive quantity of bioluminescent bacteria dispersed daily in the ocean. Based on this statement, we claim and demonstrate that bioluminescent bacteria have an ecological and a biogeochemical importance in the biological carbon pump. They catalyze and amplify the involved processes, either by aggregating or by fragmenting organic matter. We propose a synthetic representation of the bioluminescence shunt of the biological carbon pump and a future strategy to establish and quantify the impact of bioluminescence (Fig. 1). Figure 1 represents, throughout the text, the guideline of the bioluminescence shunt hypothesis of the biological carbon pump.

\section{Symbiotic bioluminescent bacteria in light organs}

In Eukaryotes, light emission has two distinct origins: intrinsic or symbiotic (Haddock et al., 2010; Nealson, 1979). Intrinsic luminescence is caused by chemicals produced by the organism itself. Most bioluminescent organisms are selfluminescent and have specialized luminous cells, i.e., photocytes, grouped inside dedicated organs called photophores (Herring, 1977). Some animals, however, are capable of luminescence using symbiotic luminous bacteria housed in elaborate and specialized organs.

\subsection{Discovery, importance, distribution and functions of light organ symbiosis}

In the late 1880s, Raphaël Dubois was among the first to suggest bacteria could be responsible for the light emitted by some animals (Harvey, 1957). In the beginning of the twentieth century, Balthazar Osorio (1912) provided clear and convincing evidence of such symbiosis, when luminescent bacteria were described in high density within a dedicated fish gland, called the light organ (Balthazar Osorio was cited in Hickling, 1926). Since then, luminous bacterial symbiosis has been the subject of interest among the scientific community working on bioluminescence, to such an extent that, by the mid-twentieth century, luminescence of many organisms was thought to have bacterial origin. However, some of these assessments have been refuted later (Herring, 1977).

Bioluminescence ability is shared by about $8 \%$ of all known fish species (Paitio et al., 2016). Amongst luminous fishes, bacterial luminescence is the rule for almost half of them (48\%) (Davis et al., 2016). To date, symbiotic bacteria are recognized as responsible for the luminescence of some fishes and squids (Davis et al., 2016; Haygood, 1993; Lindgren et al., 2012). Although forms of symbiotic luminescence have been suggested for some shark species or pyrosomes (tunicates) (Dunlap and Urbanczyk, 2013; Leisman et al., 1980), no evidence of luminous bacteria has been found so far (Claes and Mallefet, 2009; Renwart et al., 2014; Widder, 2002) and a recent study has definitely rejected a bacterial origin in the velvet belly lanternshark (Duchatelet et al., 2019). Concerning luminous squids, intrinsic bioluminescence is more common, and symbiotic light organs are known in only two families (Sepiolidae and Loliginidae) (Lindgren et al., 2012; Nishiguchi et al., 2004). 


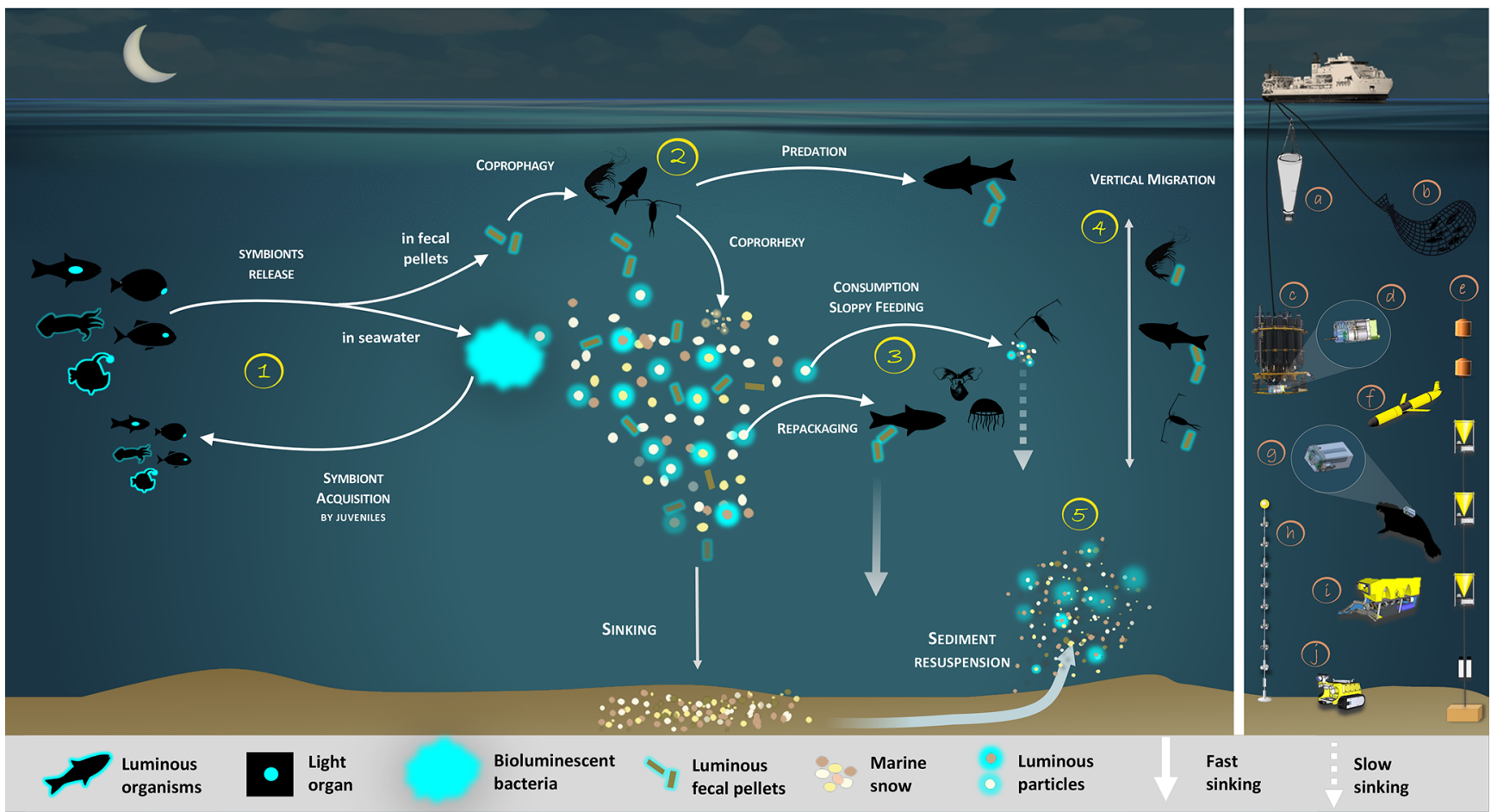

Figure 1. Bioluminescence shunt in the biological carbon pump in the ocean. Luminous bacteria in light organ symbioses are successively acquired by host (squid, fish) from the seawater while they are juveniles, then regularly released into the ocean. Depending on the light organ position, luminous bacteria are released from their guts into fecal pellets or directly into the seawater (step 1). Motile luminous bacteria colonize organic matter sinking along the water column. Bioluminescent bacteria inseminating fecal pellets and particles influence zooplankton consumption rates. Such visual markers increase detection ("bait hypothesis"), attraction and finally predation by upper trophic levels (step 2). In the mesopelagic, zooplankton and their predators feed on sinking luminous particles and fecal pellets, which form either aggregates (repackaging) of faster sinking rates or fragment organic matter (due to sloppy feeding) with slower sinking rates (step 3). Filter feeders also aggregate sinking organic matter without particular visual detection and selection of luminous matter. Diel (and seasonal) vertical migrators feeding on luminous food metabolize and release glowing fecal pellets from the surface to the mesopelagic zone (step 4). This implies bioluminescent bacteria dispersion at large spatial scales, for zooplankton or even some fish actively swimming long distances. Luminous bacteria attached to particles sink down to the seafloor, and sediment can be resuspended by oceanographic physical conditions (step 5) and consumed by epi-benthic organisms. Instruments are (a) plankton net, (b) fish net, (c) Niskin water sampler, (d) bathyphotometer, (e) sediment traps, (f) autonomous underwater vehicles, (g) photomultiplier module, (h) astrophysics optical modules ANTARES and (ij) remotely operated vehicles.

Symbiotic luminescence seems more common in benthic or coastal environments for fish and squid as well (Haygood, 1993; Lindgren et al., 2012; Paitio et al., 2016). Shallow-water fishes with luminous bacterial symbionts include flashlight fishes (Anomalopidae), ponyfishes (Leiognathidae) and pinecone fishes (Monocentridae) (Davis et al., 2016; Morin, 1983). For deep-sea fishes, anglerfishes (Ceratiodei) and cods (Moridae) are among the common examples of luminous-bacteria hosts.

Bacterial and intrinsic light organs are predominantly internal, ventrally located (Paitio et al., 2016). Many luminous organisms with ventral light organs likely use the emitted light to conceal themselves by counterillumination. This defensive strategy allows luminous species to match with the intensity, spectrum and angular distribution of the downwelling light, thus obliterating their silhou- ette and therefore avoiding dusk-active piscivorous predators (Claes et al., 2010; Johnsen et al., 2004; Warner et al., 1979). Amongst bacterial light symbioses, counterillumination has been demonstrated for the bobtail squid $\mathrm{Eu}$ prymna scolopes (Jones and Nishiguchi, 2004) and some leiognathids fish (McFall-Ngai and Morin, 1991) and hypothesized for other bioluminescent fishes (Dunlap et al., 2009; McAllister, 1967). Less common but more striking, some organisms found in the families Monocentridae and Anomalopidae and numerous deep-sea anglerfishes belonging to the suborder Ceratoidei exhibit externally located light organs colonized by bacteria (Haygood, 1993). The external light organs of flashlight fish have been demonstrated to be used to illuminate the nearby environment and detect prey (Hellinger et al., 2017), or schooling behavior (Gruber et al., 2019), while the lure of female anglerfish is generally be- 
lieved to be used for mate-finding purposes and prey attraction (Herring, 2007).

\subsection{Symbiont selection and colonization of the light organ}

Like most symbiotic bacterial associations with animals, luminous bacteria are acquired from the surrounding environment by individuals, independently of their ancestry (i.e., horizontally transmitted) (Baker et al., 2019; Haygood, 1993; McFall-Ngai, 2014). One of the best-documented symbioses is the association of Aliivibrio fischeri with the bobtail squid Euprymna scolopes (Nyholm and McFall-Ngai, 2004; Ruby, 1996). Through the easy independent cultivation of both partners in the laboratory, this symbiosis has become a perfect model for studying the process of bacterial colonization into the light organ and understanding bacteria-animal interactions, broadly speaking (Mandel and Dunn, 2016; McFallNgai, 2014).

Knowledge of the mechanisms involved in the selection and the establishment of bacterial symbionts in the squid-Vibrio symbiosis have considerably improved over the last few decades. Harvest of the luminous symbionts from the bacterioplankton is driven by microbial recognition and molecular dialog (Kremer et al., 2013; Nyholm et al., 2000; Nyholm and McFall-Ngai, 2004; Pankey et al., 2017; Schwartzman and Ruby, 2016; Visick and Ruby, 2006). Moreover, bacterial colonization of host tissues induces the morphogenesis process of the light organ and appears to signal its further development and maturation (McFall-Ngai and Ruby, 1991; Montgomery and McFall-Ngai, 1998). The luminescence feature is essential for a correct morphogenesis process of the light organ and symbiont persistence inside (McFall-Ngai et al., 2012; Visick et al., 2000).

While the bobtail squid model provides a window to understand the establishment of such symbioses, this system cannot be systematically transferred to other bacterial luminous symbioses. Although less well-known, the other associations are no less important and many questions remain unsolved since they might be harder to study.

To date, 11 bacterial species are known to be involved in light organ symbioses (Table 1). In a light organ, the bacterial population is most of the time monospecific (Dunlap and Urbanczyk, 2013; Ruby, 1996).

Considering that fish and squid housing luminous bacteria are never found without symbionts in nature, the symbiosis appears obligatory for hosts (Haygood, 1993). In contrast, most symbiotic bacteria are viable outside the light organ, and thus are considered to be facultatively symbiotic. These facultative symbiotic bacteria are readily culturable under laboratory conditions, outside the host light organ. Exceptions have been highlighted for the luminous symbionts of two groups of fish, the flashlight fish and the deep-sea anglerfish (Dunlap and Kita-tsukamoto, 2006; Haygood and Distel, 1993). Indeed, despite the fact that the bacterial origin of the light was proved by microscopic observation and that genes from luminous bacteria were amplified (Haygood and Distel, 1993), bacterial cultivation has not yet been successful. Thanks to the emergence of genome sequencing, the complete genome of these symbionts has been reported in the last years. Analyses revealed a genome reduction in size by about $50 \%$ and $80 \%$ for anglerfish and flashlight fish symbionts, respectively, compared to facultative luminous symbionts or free-living relatives (Hendry et al., 2014, 2016, 2018). Genome reduction is a common trait shared by bacteria involved in obligatory symbiosis (Moran et al., 2009) and explains the inability of these symbionts to grow in laboratory cultures. Flashlight fish and anglerfish symbionts appear to be obligately dependent on their hosts for growth, as some metabolic capacities (e.g., genes necessary for amino acid synthesis) are absent in the genome.

\subsection{Light organs are under well-established controls}

Although light organs can differ in form, size or location according to the host (see Table 1), some structural and functional features are common for all of them. Luminous bacteria are densely packed within tubules which connect to the exterior of the light organ (Haygood, 1993; Nealson, 1979). The host provides nutrients and oxygen to the tubules through a highly vascularized system (Tebo et al., 1979). Bioluminescent bacteria emit light continuously in the light organ, as they do in laboratory cultures (Nealson and Hastings, 1979). However, the light intensity varies over time. As for self-luminescent fish, bacterial light organs have evolved with a multitude of adaptations of tissue, to serve as reflectors, diffusers, screens and light-conducting channels (Haygood, 1993; Munk et al., 1998). Such anatomical features assist in directing and enhancing light output (Sparks et al., 2005). In addition, the host can control the light diffusion through different mechanisms, which may be external lids, chromatophores, organ rotation, filters, occlusion with a shutter or muscle contraction (Hansen and Herring, 1977; Herring, 1977; Johnson and Rosenblatt, 1988). As an example, for counterillumination, controlling the intensity of light output gives the host a better camouflage, adapting its silhouette to environmental changes in light (Jones and Nishiguchi, 2004; McFall-Ngai and Morin, 1991). For intraspecies communication, it permits the production of sudden flashes or a specific signal/rhythm of light (e.g., schooling behavior, Gruber et al., 2019).

In squid-Vibrio symbiosis, bacterial luminescence genes are regulated with a quorum-sensing system, a cell-densitydependent process. When the cell density reaches a certain level, autoinducers responsible for triggering the synthesis of the genes involved in light emission are accumulated in sufficient amounts, and light is emitted (Nealson et al., 1970; Verma and Miyashiro, 2013). Interestingly, A. fischeri produces a higher level of luminescence within the light organ than in laboratory cultures, despite a similarly high 
Table 1. List of luminous bacterial species found in light organ symbiosis in fishes and squids. The diagrammatic fish, from Nealson and Hastings (1979), was used to indicate, in blue, the approximate locations of the light organ of the different families of symbiotically luminous fishes. $E$ indicates an external expulsion of the bioluminescent bacteria, directly into the seawater. $I$ indicates an internal expulsion of the bioluminescent bacteria, in the digestive tract. $(E)$ or $(I)$ indicate a putative localization of the expulsion.

\begin{tabular}{|c|c|c|c|c|}
\hline Species & Host collection & Hosts & Light organ location & \\
\hline $\begin{array}{l}\text { Alïvibrio fischeri } \\
\text { (Vibrio fischeri) }\end{array}$ & $\begin{array}{l}\text { Euprymna spp. } \\
\text { Western Pacific } \\
\text { (Fidopiastis et al., 1998) } \\
\text { Sepiola spp. } \\
\text { Mediterranean Sea, } \\
\text { European Atlantic coast, } \\
\text { Japan, Philippines } \\
\text { (Fidopiastis et al., 1998) } \\
\text { Moconcentris japonica } \\
\text { Japan } \\
\text { (Dunlap et al., 2007) } \\
\text { Cleidopus gloriamaris } \\
\text { East coast of Australia } \\
\text { (Fitzgerald, 1977) } \\
\text { Caelorinchus spp. } \\
\text { Taiwan (C. formosanus) } \\
\text { Japan (C. multispinulosus) } \\
\text { (Dunlap et al., 2007) }\end{array}$ & $\begin{array}{c}\text { SEPIOLIDAE } \\
\text { Euprymna spp. } \\
\text { E. morsei } \\
\text { E. berryi } \\
\text { E. scolopes } \\
\text { E. tasmanica } \\
\text { Sepiola spp. } \\
\text { S. affinis } \\
\text { S. atlantica } \\
\text { S. intermedia } \\
\text { S. ligulata } \\
\text { S. robusta } \\
\\
\text { MONOCENTRIDAE } \\
\text { Monocentris spp. } \\
\text { M. japonica } \\
\text { Cleidopus spp. } \\
\text { C. gloriamaris } \\
\text { MACROURIDAE } \\
\text { Caeloninchus } \text { spp. } \\
\text { C. formosanus } \\
\text { C. multispinulosus }\end{array}$ & & $\mathbf{E}$ \\
\hline Aliivibrio thorii & $\begin{array}{l}\text { Sepiola affinis } \\
\text { Mediterranean Sea } \\
\text { (Fidopiastis et al., 1998; Ast et al., 2007) }\end{array}$ & $\begin{array}{l}\text { SEPIOLIDAE } \\
\text { Sepiola spp. } \\
\text { S. affinis }\end{array}$ & & $\mathbf{E}$ \\
\hline Alïvibrio wodanis * & $\begin{array}{l}\text { Sepiola spp. } \\
\text { Mediterranean Sea } \\
\text { (Fidopiastis et al., 1998; Ast et al., 2007) }\end{array}$ & $\begin{array}{l}\text { SEPIOUIDAE } \\
\text { Sepiola spp. } \\
\text { S. affinis } \\
\text { S. robusta }\end{array}$ & & $\mathbf{E}$ \\
\hline $\begin{array}{l}\text { Photobacterium } \\
\text { kishitanii }\end{array}$ & $\begin{array}{l}\text { Opisthoproctus spp. } \\
\text { Atlantic Ocean (O. grimaldi) } \\
\text { Atlantic Ocean and Indian Ocean (O. } \\
\text { soleatus) } \\
\text { (Haygood et al., 1992; Dunlap et al., 2007) } \\
\text { Chlorophthalmus spp. } \\
\text { Japan } \\
\text { (Dunlap et al., 2007) } \\
\text { Caelorinchus spp. } \\
\text { Taiwan (C. kishinouyel) } \\
\text { Japan (Other species) } \\
\text { (Dunlap et al., 2007) } \\
\text { Malacocephalus laevis } \\
\text { Indian Ocean } \\
\text { (Dunlap et al., 2007) } \\
\text { Ventrifossa spp. } \\
\text { Japan (V. garmani and V. longibardata) } \\
\text { Taiwan (V.rhidodorsalis) } \\
\text { (Dunlap et al., 2007) } \\
\text { Physiculus japonicus } \\
\text { Japan } \\
\text { (Dunlap et al., 2007) } \\
\text { Aulotrachichthys prosthemius } \\
\text { Japan } \\
\text { (Ast and Dunlap, 2004) } \\
\text { Acropoma hanedai } \\
\text { Taiwan } \\
\text { (Kaeding et al., 2007; Dunlap et al., 2007) }\end{array}$ & $\begin{array}{c}\text { OPISTHOPROCTIDAE } \\
\text { Opisthoproctus spp. } \\
\text { O. gnimaldii } \\
\text { O. soleatus } \\
\text { CHLOROPHTHALMIDAE } \\
\text { Chlorophthalmus spp. } \\
\text { C. acutifrons } \\
\text { C. albatrossis } \\
\text { C. nigromarginatus } \\
\text { MORIDAE } \\
\text { Physiculus spp. } \\
\text { P. japonicus } \\
\\
\text { MACROURIDAE } \\
\text { Caelorinchus spp. } \\
\text { C. anatirostris } \\
\text { C. denticulatus } \\
\text { C. fasciatus } \\
\text { C. hubbsi } \\
\text { C. japonicus } \\
\text { C. kamoharai } \\
\text { C. kishinouyei } \\
\text { ACROPOMATIDAE } \\
\text { Acropoma spp. } \\
\text { A. hanedai } \\
\text { Malacocephalus spp. } \\
\text { M. laevis } \\
\text { TRACHICHTHYIDAE } \\
\text { Aulotrachichthys spp. } \\
\text { A. prosthemius } \\
\text { Ventrifossa spp. } \\
\text { V. garmani } \\
\text { V. longibarbata } \\
\text { V. rhipidodorsalis } \\
\end{array}$ & $\int \leqslant$ & $x^{2}$ \\
\hline
\end{tabular}


Table 1. Continued.

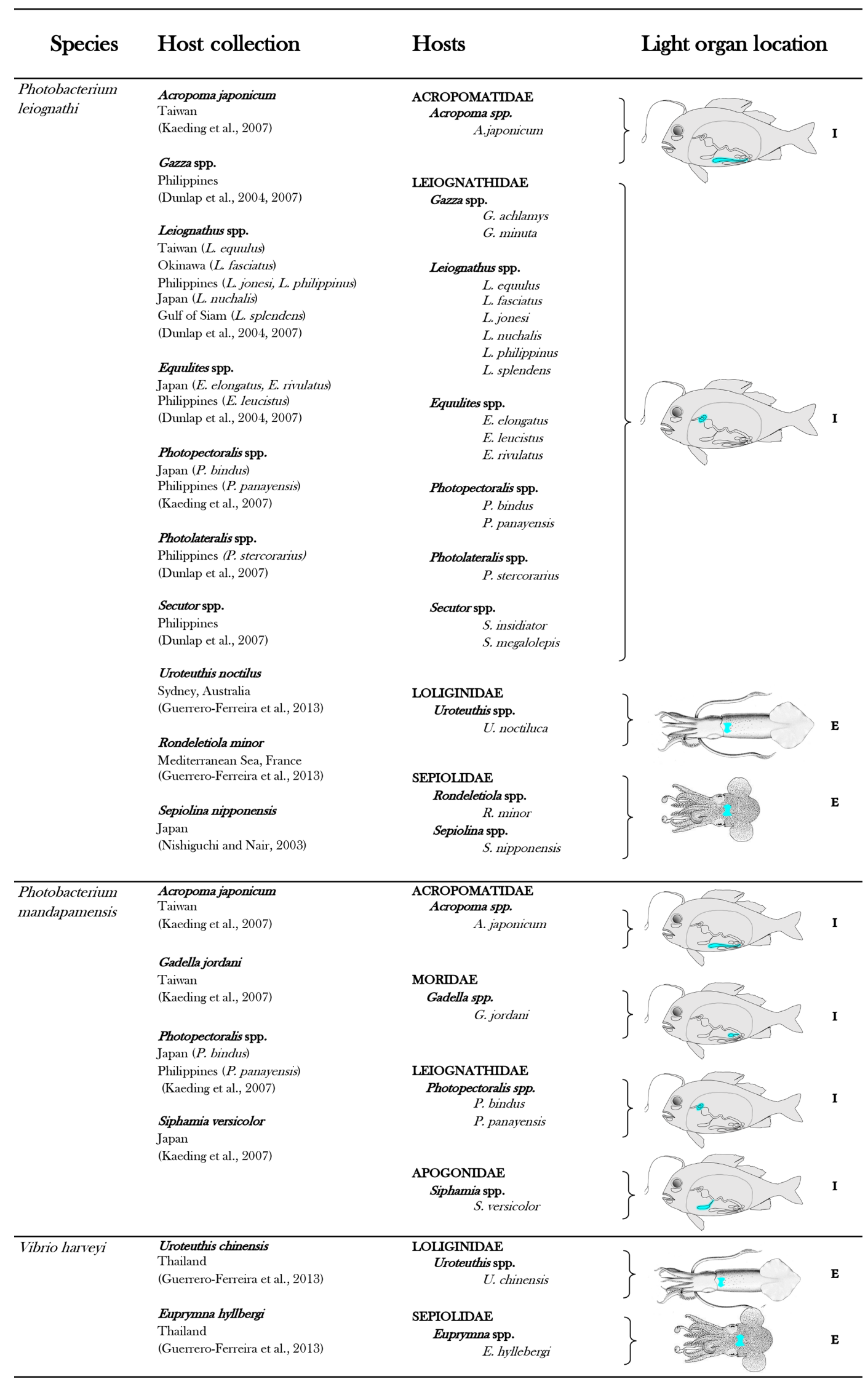


Table 1. Continued.

\begin{tabular}{|c|c|c|c|c|}
\hline Species & Host collection & Hosts & Light organ location & \\
\hline $\begin{array}{l}\text { Candidatus } \\
\text { Enterovibrio escacola }\end{array}$ & $\begin{array}{l}\text { Ceratias spp. } \\
\text { NE Altantic (C. sp) } \\
\text { Gulf of Mexico (C. uranoscopus) } \\
\text { Lynophryne maderensis } \\
\text { NE Atlantic } \\
\text { Melanocetus johnsoni } \\
\text { Gulf of Mexico and NE Atlantic } \\
\text { Melanocestus murrayi } \\
\text { Gulf of Mexico } \\
\text { Chaenophryne spp. } \\
\text { NE Atlantic } \\
\text { Oneirodessp. } \\
\text { Gulf of Mexico } \\
\text { (Baker et al,, 2019) }\end{array}$ & $\begin{array}{c}\text { CERATIDAE } \\
\text { Ceratias spp. } \\
\text { C. uranoscopus } \\
\text { C. sp } \\
\text { LINOPHRYNIDAE } \\
\text { Linophryne spp. } \\
\text { L. maderensis } \\
\text { MELANOCETIDAE } \\
\text { Melanocetus spp. } \\
\text { M. johnsoni } \\
\text { M. murrayi } \\
\text { ONEIRODIDAE } \\
\text { Chaenophryne spp. } \\
\text { C. longiceps } \\
\text { C. sp } \\
\text { Oneirodes spp. } \\
\text { O. sp }\end{array}$ & & $\mathbf{E}$ \\
\hline $\begin{array}{l}\text { Candidatus } \\
\text { Enterovibrio luxaltus }\end{array}$ & $\begin{array}{l}\text { Cryptopsaras couesï } \\
\text { Gulf of Mexico and NE Atlantic } \\
\text { (Baker et al., 2019) }\end{array}$ & $\begin{array}{c}\text { CERATIIDAE } \\
\text { Cryptopsaras spp. } \\
\text { C. couesii }\end{array}$ & & $\mathbf{E}$ \\
\hline $\begin{array}{l}\text { Candidatus } \\
\text { Photodesmus } \\
\text { blepharus }\end{array}$ & $\begin{array}{l}\text { Photoblepharon spp. } \\
\text { Pacific Ocean (P. palpebratus) } \\
\text { Western Indian Ocean (P. steinitzi) } \\
\text { (Hendry and Dunllap, 2014) }\end{array}$ & $\begin{array}{c}\text { ANOMALOPIDAE } \\
\text { Photoblepharon spp. } \\
\text { P. palpebratus } \\
\text { P. steinitzi }\end{array}$ & & $\mathbf{E}$ \\
\hline $\begin{array}{l}\text { Candidatus } \\
\text { Photodesmus } \\
\text { katoptron }\end{array}$ & $\begin{array}{l}\text { Anomalops spp. } \\
\text { Philippines } \\
\text { (Hendry and Dunlap, 2011) }\end{array}$ & $\begin{array}{l}\text { ANOMALOPIDAE } \\
\text { Anomalops spp. } \\
\text { A. katoptron }\end{array}$ & & $\mathbf{E}$ \\
\hline
\end{tabular}

cell density (Boettcher and Ruby, 1990). Hence, Verma and Miyashiro (2013) suggested that the light organ environment offers specific conditions such as the levels of oxygen, iron or phosphate, to enhance bacterial light emission. Here again, while the control mechanisms of the squid-Vibrio symbiosis are well-understood, those of the other symbioses remain enigmatic and there are indications that they may vary. For example, the absence of the quorum-sensing-gene detection in anglerfish and flashlight fish symbionts suggests a constitutive light emission by the bacteria (Hendry et al., 2016, 2018).

For all symbioses, luminous symbionts, within the light organ, reach a very high density which reduces the oxygen availability, essential for the light reaction. Such oxygen limitation leads to a decrease in the specific luminescence activity (Boettcher et al., 1996). The bacterial population inside the light organ is regulated by the host, by coupling the restriction of the growth rate and the expulsion of symbionts. Growth repression is thought to reduce the energetic cost of the symbiosis to the host (Haygood et al., 1984; Ruby and Asato, 1993; Tebo et al., 1979). Additionally, since luminous bacteria are densely packed inside tubules communicating with the exterior of the light organ (Haygood, 1993), the cell number of symbionts is regulated by the regular expulsion of most of the bacterial population, followed by a period of regrowth of the remaining symbionts. Concerning the wellknown squid-Vibrio symbiosis, its daily release is highly cor- related with the diel pattern of the host behavior. Indeed, the bobtail squid expels $95 \%$ of the luminous symbionts in the surrounding environment at dawn, the beginning of its inactive phase. The remaining $5 \%$ of $A$. fischeri grow through the day and the highest concentration is reached at the end of afternoon, at the nocturnal active phase of the squid (Nyholm and McFall-Ngai, 2004; Ruby, 1996). Currently, with the exception of the squid-Vibrio symbiosis, accurate data on the symbiont release are still largely unknown. Indeed, the frequency of release may vary and occur more than once a day as has been shown for some flashlight and pinecone fishes (Haygood et al., 1984).

Regular expulsion of symbionts maintains favorable conditions in the light organ for the bacterial population, but it also seeds the environment with luminous symbionts for colonization of the next host generation. The consequence is a release of a huge quantity of bioluminescent bacteria in the seawater, inducing a major contribution to the ocean microbiome. To make it more concrete and provide an order of magnitude, two examples are proposed. Using laboratory experiments on different fishes (Monocentridae, Anomalopidae), Haygood et al. (1984) estimated a release of between $10^{7}$ and $10^{9}$ bioluminescent bacterial cells per day and per individual. Another study on the Hawaiian bobtail squid (E. scolopes) has estimated that the squid expels about $5 \times 10^{8}$ bioluminescent bacterial cells per day and per individual (Lee and Ruby, 1994). These discharges lead to a regular 
luminous-bacteria enrichment of the areas inhabited by these organisms.

Depending on the anatomical location of the light organ (see Table 1), luminous symbionts are released through pores or ducts into the surrounding seawater or into the digestive tract (Haygood, 1993; Nealson and Hastings, 1979). An enteric lifestyle has indeed been suggested for the luminous bacteria (Ruby and Morin, 1979; Nealson, 1979).

\section{Enteric associations in marine-fish guts}

The gastrointestinal (GI) tract of an animal is a very complex and dynamic microbial ecosystem (Nayak, 2010). Current knowledge and concepts of GI microbiota derive from studies on humans or other terrestrial mammals. In contrast, GI ecosystems of marine inhabitants have yet received little attention, and studies focused on farmed fish or commercially important species of fish. Whether aerobes or anaerobes are the main group in the microbiota in fish intestines is still discussed (Romero et al., 2014). For marine fish, the dominant members seem to be facultative anaerobes (Wang et al., 2018). Considering that most of the bioluminescent bacteria are facultative anaerobes (Ramesh et al., 1990; Reichelt and Baumann, 1973), it is not surprising to find them in gut niches.

Although luminescence of dead fish was a well-known phenomenon, one of the first mentions of the presence of luminescent bacteria in fish slime and intestinal contents is only from the beginning of the 1930s (Stewart, 1932). Since then, the high occurrence of luminous bacteria in fish intestines has been reported in many studies (Baguet and Marechal, 1976; Barak and Ulitzur, 1980; Liston, 1957; Makemson and Hermosa, 1999; O'Brien and Sizemore, 1979; Ramesh and Venugopalan, 1988; Reichelt and Baumann, 1973; Ruby and Morin, 1979). Most hosts with an internal light organ release luminous bacteria into the digestive tract via ducts (Haygood, 1993; Nealson and Hastings, 1979) and thus may largely contribute to their abundance in luminous fish intestines. However, many fishes without a light organ also harbor luminescent bacteria in their gut (Makemson and Hermosa, 1999), which clearly demonstrates the existence of other sources of enteric luminous bacteria. Through the gut-content analysis of 109 fish species from the Gulf of Oman, Makemson and Hermosa (1999) showed that the relative proportion of the occurring culturable luminous bacteria was strongly variable. While some fish guts harbor more than $80 \%$ luminous bacteria, some others have between $20 \%$ and $50 \%$, and a minority have none detected, with a substantial intra- and interspecies fish variability. Like other authors, Makemson and Hermosa (1999) highlighted $V$. harveyi and $P$. phosphoreum as the dominant luminous species found in fish guts (O'Brien and Sizemore, 1979; Reichelt and Baumann, 1973; Ramesh and Venugopalan, 1988).
Seasonal variations have been observed in both luminous bacterial density (Liston, 1957; Ramesh and Venugopalan, 1988) and predominant species (Bazhenov et al., 2019). Such variability is not surprising since it is inferred from the structure and composition of the gut microbiota of fish, which are influenced by a series of factors, including (i) host factors (e. g genetics, gender, weight, age, immunity, trophic level); (ii) environmental factors such as water, diet and surrounding environment; (iii) microbial factors (e.g., adhesion capacity, enzymes and metabolic capacity); (iv) and individual variations and day-to-day fluctuations (Nayak, 2010; Sullam et al., 2012; Wang et al., 2018). Interestingly, a high proportion of luminescent bacteria $(>70 \%$ ) has been found in the gut of an Atlantic halibut recently fed, while an individual male in spawning condition, which had not eaten recently, had a flora dominated by non-luminescent microorganisms (Verner-Jeffreys et al., 2003). This result underlines the link between food ingestion and abundance of luminous bacteria and suggests that they do not persist within the halibut gut once the feces are eliminated. This also suggests that luminous bacteria are then released with the feces in the water column. Makemson and Hermosa (1999) have reported a slightly higher proportion of culturable luminous bacteria in herbivorous fish compared to carnivorous fish. They also emphasized the higher incidence of luminescent bacteria in pelagic than in reef-associated fish, and filter-feeder-fish guts contain more luminous bacteria compared to other feeding types (e.g., predator). For bigger fishes, a potential introduction source of luminous bacteria into the gut could be the ingestion of smaller prey bearing a bacterial light organ. For all organisms, enteric luminous bacteria may be transferred to the gut bacterial community of their predators.

It should be emphasized that investigations on microbial communities of fish have long been limited by the use of culture-dependent methods (Austin, 2006; Romero et al., 2014). The fish-gut microbiota has been reported to be particularly of low cultivability, with less than $0.1 \%$ of the total microbial community cultivable (Zhou et al., 2014), although the level of cultivability may be taxon dependent (Ward et al., 2009). Today, advanced molecular techniques offer a wide variety of culture-independent methods, such as next-generation sequencing (NGS), for analyzing fish microbiota (Tarnecki et al., 2017).

Several studies using gene sequencing based on $16 \mathrm{~S}$ rRNA to characterize the gut microbiome of fish have reported the genus Photobacterium as the most abundant in the guts of salmon and trout (Bagi et al., 2018; Givens et al., 2015; Michl et al., 2019; Riiser et al., 2018), shark (Michl et al., 2019), and Atlantic cod (Bagi et al., 2018; Givens et al., 2015; Michl et al., 2019; Riiser et al., 2018). Other studies reported the presence of Photobacterium spp. in the gut of hydrothermal shrimp (Durand et al., 2009), in some adult anglerfish (Freed et al. 2019) and, seasonally variable, in the gut of Norway lobster (Meziti et al., 2010). However, because not all Photobacterium spp. have luminescence ability, it is important 
to be able to resolve dominant operational taxonomic unit (OTU) at the species level, which, most of the time, is not possible with a $16 \mathrm{~S}$ rRNA barcoding sequencing approach. The emergence of multi-gene approaches offers more detailed insights into the taxonomic diversity of these communities (i.e., species level). Thus, using metagenomic shotgun sequencing, two independent and recent works on wild Atlantic cods also concluded Photobacterium spp. domination and have been able to go deeper into the taxonomic identification. Le Doujet et al. (2019) demonstrated that the Photobacterium genus represents $78 \%$ of all present genera and identified the $P$. phosphoreum clade as the most abundant Photobacterium lineage. According to Riiser et al. (2019), the luminous species $P$. kishitanii constitutes over $26 \%$ of the Vibrionales community, which is the dominant clade, and the authors underlined the presence of the functional lux genes, the light-emission-involved genes. Therefore, recent metagenomic studies seem to confirm the trend of a high occurrence of luminous bacteria in fish intestines.

\section{Luminous bacteria and the biological carbon pump}

As previously discussed, light organs and guts act as a source for luminous-bacteria persistence in the oceans. Therefore, luminous bacteria are widespread in the ocean. They can be found as free-living forms or attached to particles (Nealson and Hastings, 1979; Ramesh and Mohanraju, 2019; Ruby et al., 1980).

\subsection{Bioluminescent bacteria in the water column}

Qualitative and quantitative studies showed that the luminous bacteria are dynamic over time and space. Seasonal variations have been identified, in both abundance and predominant species (O'Brien and Sizemore, 1979; Ruby and Nealson, 1978; Yetinson and Shilo, 1979). A wide variability has been observed in species repartition over depth and between geographic areas (DeLuca, 2006; Gentile et al., 2009; Nealson and Hastings, 1979; Ramaiah and Chandramohan, 1992; Ruby et al., 1980). Horizontal, vertical and seasonal variations were presumed to reflect physiological preferences most of the time, and particularly temperature or salinity sensitivity (Orndorff and Colwell, 1980; Ramesh et al., 1990; Ruby and Nealson, 1978; Shilo and Yetinson, 1979; Yetinson and Shilo, 1979). Some works mentioned that symbiotic niches, such as light organs and enteric tracts, may serve to inoculate the planktonic population (Nealson et al., 1984; Nealson and Hastings, 1979; Ramesh et al., 1990; Ruby et al., 1980). To our knowledge, very few studies focused intensively on the contribution of species-specific symbiotic associations on the occurrence and distribution of luminous bacteria in the surrounding water. Amongst these rare studies, Lee and Ruby (1994) reported that the abundance of $A$. fischeri, the luminous symbiont of the Hawaiian squid $E$. scolopes was 24 to 30 times higher, in both water column and sediments, in areas inhabited by the squids than in similar locations where squids were not observed.

Bioluminescent bacteria also seem to be the cause of the spectacular and still largely unexplained events, so-called milky seas (Lapota et al., 1988; Nealson and Hastings, 2006). Milky seas are characterized by an unusual brightness on the ocean surface and extend over such a large area that the light emitted is detectable from space (Miller et al., 2005). The light emission pattern of milky seas is continuous and homogeneous, which is consistent with light emission from bacteria and easily distinguished from blooms of dinoflagellates.

\subsection{Bioluminescent bacteria attached to particles}

Outside of spatially restricted niches, such as light organ or gut environments, the role of the dispersed luminous cells in the marine environment was a matter of debate, and it was thus mentioned that non-symbiotic bacteria may have no ecological significance (Hastings and Greenberg, 1999; Nealson and Hastings, 1979). However, Herren et al. (2004) suggested that luminous bacteria are more often attached to particles than free-living, which was confirmed by Al Ali et al. (2010). Many bacteria, including bioluminescent bacteria (Ruby and Asato, 1993; Zhang et al., 2016), can develop swimming behavior to colonize the sinking organic material, therefore reaching a cell density 100 to 10000 times higher than in the water column (up to $10^{8}$ to $10^{9}$ cells $\mathrm{mL}^{-1}$ ) (e.g. Ploug and Grossart, 2000).

Bacteria that glow on particles can attract macroorganisms. After being ingested, they will find a more favorable environment to live and grow in their gut (Andrews et al., 1984; Ruby and Morin, 1979). Actually, this is the preferred current hypothesis that supports a positive selection related to the dispersion and propagation of the bacteria. Indeed, luminous bacteria growing on particulate matter could produce enough light to be visible by other organisms. For bacterial species with light production under cell-density control (i.e., under quorum-sensing regulation), the high cell concentration reached on particles can allow the sufficient accumulation of the autoinducers, and thus the emission of light for attracting predators. For species for which light production is not subject to cell-density control (i.e., not under quorumsensing regulation) (Tanet et al., 2019), to be able to produce light at a very low cell concentration could give them an advantage. Continuously glowing bioluminescent emissions are thought to attract predators (Nealson and Hastings, 1979). In the water column, the glowing bacteria aggregated on particles would lead to the detection, attraction, ingestion and decomposition of particles by larger organisms. Grazers would consume luminous matter at a higher rate than invisible particles. Being consumed and ending up in the gut, bacteria would benefit from a more suitable environment regarding the growth conditions and the nutrient accessibility. In the open ocean, and particularly in deep regions, where 
sparse nutrient supply prevails, nutrient-rich gut niches of the surrounding animals could appear as an oasis of life for bacteria. This dispersion hypothesis has also been strongly consolidated by field data where bacterial bioluminescence was observed in freshly egested fecal pellets and in materials collected from sediment traps (Andrews et al., 1984), as well as by laboratory experiments where glowing zooplankton were preferentially ingested by fishes (Zarubin et al., 2012).

The copiotrophic trait of luminous bacteria is another point supporting their particle-attached lifestyle. Bacterial population colonizing nutrient-rich environments (e.g., floating carcass, marine snow, fecal pellets or the gut tract of a marine eukaryote) are defined as copiotrophs, by opposition to the oligotrophs which are members of free-living microbial populations (Lauro et al., 2009). All luminous Vibrionaceae, except reduced genome symbionts, possess two chromosomes in their genome (Boyd et al., 2015; Zhang et al., 2016), with a high copy number of rRNA operons. Such genomic features, a large genome size and multiple rRNA operons, are considered to be an adaptation for a copiotrophic lifestyle (Klappenbach et al., 2000; Lauro et al., 2009). Copiotrophs are thought to have strong adaptability skills, permitting them to survive long enough between two nutrient-rich environments (Yooseph et al., 2010).

Fish guts could also act as an enrichment vessel for the growth of luminous bacteria, and thus enhance their propagation (Nealson and Hastings, 1979; Ramesh and Venugopalan, 1988). When expelled with feces, enteric luminous bacteria can be easily isolated from the fresh fecal material. This fecal luminescence increased in intensity over a matter of hours, proving that luminous bacteria survive the digestive process and can proliferate on such organic material (Ruby and Morin, 1979). Hence, fish feces appear to be an important source of viable luminous bacteria in the marine environment and could affect both the distribution and the species composition of luminous populations. The luminescence of fecal particles has been reported numerous times and is always associated with luminous bacteria, due to the observation of continuous light emission or direct isolation (Andrews et al., 1984; Ramesh et al., 1990; Raymond and DeVries, 1976; Ruby and Morin, 1979; Zarubin et al., 2012).

In comparison with free-living luminous bacteria, few studies have focused on bioluminescence of marine snow and fecal pellets. Yet, observations on materials collected from sediment traps revealed light emission in $70 \%$ of all samples, with two distinct patterns of light kinetics, probably due to the presence of different luminescent organisms (Andrews et al., 1984). Surface-sample (above $60 \mathrm{~m}$ depth) analyses reported that more than $90 \%$ of the luminous-aggregate samples exhibited bacterial luminescence (Orzech and Nealson, 1984). Another study (between 2 and $17 \mathrm{~m}$ depth) also reported a large part of luminous marine snow, but more likely due to dinoflagellates (Herren et al., 2004).

\subsection{Bioluminescent bacteria in the sediments}

Information relative to luminous bacteria in sediment is also limited. It is known that bioluminescent bacteria can be isolated from sediment samples (Ramesh et al., 1990), but rare data exist about their distribution or abundance. In some sediment samples, occurrence of luminous bacteria among total heterotrophic bacteria could reach up to $70 \%$, with seasonal variations (Ramesh et al., 1989), although less pronounced than in the water column (O'Brien and Sizemore, 1979). The main sources of luminous bacteria in sediments are likely the glowing sinking marine snow and benthic or demersal hosts, harboring symbiotic light organs with regular discharges.

More recently, sediment resuspension events (Durrieu de Madron et al., 2017) were correlated with newly formed deep-water events and deep-sea bioluminescent events recorded in the NW Mediterranean Sea (Martini et al., 2014; Tamburini et al., 2013a). Since the presence of active luminous bacteria has been demonstrated on the site (Martini et al., 2016), it has been hypothesized that resuspended luminescent bacteria present in sediment can be part of these luminescence events (Durrieu de Madron et al., 2017). Additionally, dense water formation, conveying particulate organic matter, could further increase luminous-bacteria proliferation and activity (Tamburini et al., 2013a).

\subsection{How do bioluminescent bacteria impact the biological carbon pump?}

Based on the ecological versatility of the bacterial bioluminescence reviewed above, we propose reconsidering the classical view of the fate of organic matter in the oceans. Figure 1 represents the guideline of the bioluminescence shunt hypothesis of the biological carbon pump.

Bioluminescent bacterial emissions are continuous over time and such a characteristic is thought to attract predators. Indeed, the light from bioluminescence contrasts well against the dim or dark background of the ocean depths. In the bathypelagic zone (1000-4000 m), where no daylight remains, bioluminescent emissions are considered the major visual stimulus (Warrant and Locket, 2004; Widder, 2002). For these reasons, symbiotic associations in light organs have been selected as an advantage for hosts (fish or squid). Luminous bacterial symbionts are successively acquired by juveniles and released into the seawater to control population concentration (Fig. 1, step 1). As indicated previously, the release of bioluminescent bacteria from light organs and fecal pellets could represent a huge quantity of bioluminescent bacteria in the water column. On dead organisms, luminous bacteria present in the gut of the host could initiate rapid propagation and decomposition of the host body and result in the formation of luminous debris in the marine environment. Based on the increase in light emission observed on dead marine animals, Wada et al. (1995) argue that, upon the 
death of the host, enteric luminous bacteria may have an important saprophytic lifestyle.

Recent studies underlined that fish vision is very-welladapted to the detection and location of point-source bioluminescence (de Busserolles and Marshall, 2017; Mark et al., 2018; Musilova et al., 2019; Paitio et al., 2016; Warrant and Locket, 2004). Although less intensively documented than fishes, the crustacean (copepods, amphipods, isopods, etc.) visual system is also reported to have a sensitivity shift to bluer wavelengths, which aids their bioluminescence detection (Cohen and Forward, 2002; Frank et al., 2012; Marshall et al., 1999; Nishida et al., 2002). In the laboratory, Land et al. (1995) demonstrated that amphipods were attracted to a blue-light-emitting diode. Unfortunately, and despite these statements, rare studies have investigated the effect of bioluminescence on the ingestion rates of predators (Fig. 1, step 2). To our knowledge, the only one known is from Zarubin et al. (2012), who demonstrated that zooplankton is attracted to luminous particles and feeds on the luminousbacteria-rich organic matter. Because of the ingestion of the luminous bacteria, the zooplankton itself starts to glow. Then, Zarubin et al. (2012) experimentally measured the 8-timeshigher ingestion rate of glowing zooplankton by fishes, compared to non-luminous zooplankton.

Glowing bacteria have been observed attached to particles of organic matter, marine snow and fecal pellets (Fig. 1, from symbionts in guts in step 1 and through predation in step 2) sinking into the deep ocean. Thus, while sinking into the deep, these glowing bacteria living on organic carbon particles (marine snow, fecal pellets, etc.) would lead to the detection, attraction, ingestion and decomposition of particles by larger organisms. Consumers would ingest luminous matter at a higher rate than invisible particles and consequently will increase luminous-microorganism dispersion by the egestion of fecal pellets. Bioluminescent sinking material should accelerate the consumption of organic matter by attracting grazing organisms. Interestingly, bacteria associated with animal guts are thought to be particularly adapted to high hydrostatic pressure (Deming et al., 1981; Ohwada et al., 1980; ZoBell and Morita, 1957). Indeed, certain bioluminescent bacteria resist high hydrostatic pressure (Brown et al., 1942), and some of them have a higher growth rate and emit more light than at atmospheric pressure (Martini et al., 2013). Such piezotolerance, or piezophile lifestyle, is undoubtedly an advantage for luminous bacteria attached to particles that are exposed to pressure variations during the sinking-particle fluxes (Tamburini et al., 2013b). The addition of these bioluminescent tags on particles has two indirect impacts (Fig. 1, steps 2 and 3). First, due to aggregate fragmentation by sloppy feeding and coprorhexy, fast-sinking particles are transformed into slow-sinking or suspended particles. Fragmentation has been shown to be the primary process controlling the sequestration of sinking organic carbon (Briggs et al., 2020). The second possibility is that organic matter ingestion leads to aggregation by repackaging, and the egested pellets of higher density are fast-sinking particles. Filter-feeder plankton, without visual detection and food selection by light, will also passively contribute to such aggregation or fragmentation of particles. For these organisms, bioluminescence can even have a negative effect since they can be identified by the luminous material filtered. Additionally, the consumption of organic material colonized by bioluminescent bacteria increases their dispersal rate provided by migrating zooplankton and even more so by actively swimming fish, following the conveyor-belt hypothesis (Grossart et al., 2010) (Fig. 1, step 4). After being ingested, bacteria (including luminous ones), attached to the particles consumed by zooplankton and fish, stay in their digestive tract. At night, these organisms migrate in the upper part of the water column and release feces in niches and at depth that, eventually, would not have been otherwise colonized by luminous bacteria. This dispersion, due to the expelling of luminous feces, is several orders of magnitude greater than that of waterborne free bacteria. Zooming on the carbon fluxes at the level of a gravitational sinking particle (Fig. 2), the bioluminescence shunt hypothesis implies that the bacterial glow of this particle increases the distance of visual detection. Such a distance can be up to several tens of meters according to Warrant and Locket (2004) and probably depends on the bioluminescent bacterial concentration and the visual perception of the organisms.

Sediment resuspension is another process implying the consumption of luminous bacteria by higher trophic levels (Fig. 1, step 5). This potentially re-inseminates bacteria into the bioluminescence loop through the consumption by epibenthic organisms.

Considering this bioluminescence shunt hypothesis, all the processes described above show that bioluminescence affects the biological gravitational carbon pump (Boyd et al., 2019), either by increasing the carbon sequestration into the deep ocean or by slowing down the sinking rate of particles and consequently increasing their degradation and the remineralization rate. Bioluminescence and especially luminous bacteria may therefore influence the export and sequestration of biogenic carbon in the deep oceans (either positively or negatively). A better quantification of these processes and impacts in the biological carbon pump is a requirement in future studies.

\section{Past and future instrumentation for bioluminescence assays}

\subsection{Previous sampling methods to describe diversity and abundance of luminous bacteria}

In the existing literature, to estimate the diversity and the distribution of bioluminescent bacteria, studies were based on a restricted number of sampling methods and instruments. These methods focused either on environmental samplings 


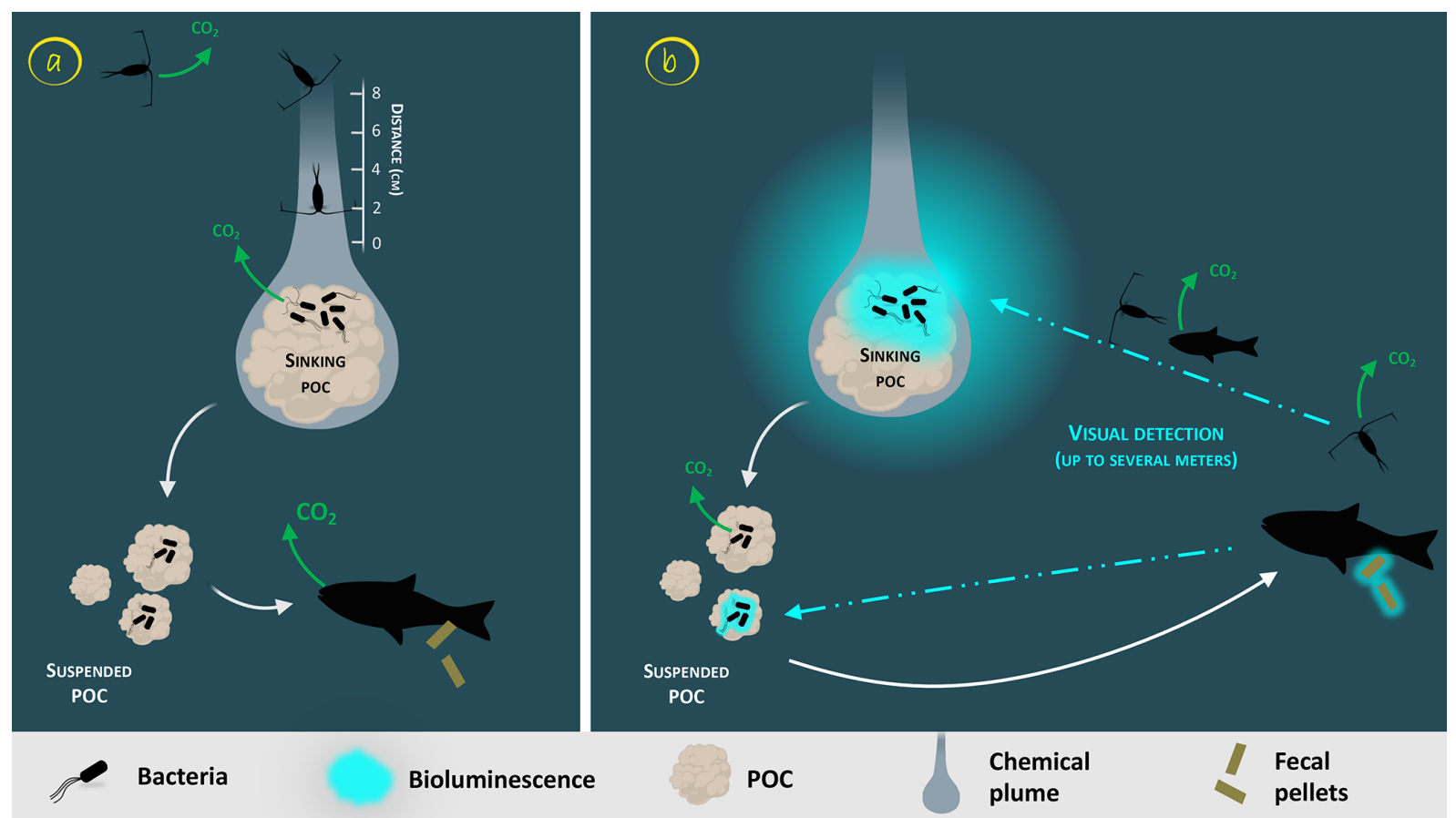

Figure 2. Zoom on the carbon fluxes at the level of a gravitational sinking particle (inspired by Azam and Long, 2001). The sinking POC is moving downward followed by the chemical plume (Kiørboe, 2011). The plain white arrows represent the carbon flow. Panel (a) represents the classical view of a non-bioluminescent particle. The length of the plume is identified by the scale on the side (Kiørboe and Jackson, 2001). Panel (b) represents the case of a glowing particle in the bioluminescence shunt hypothesis. Bioluminescent bacteria are represented aggregated onto the particle. Their light emission is shown as a bluish cloud around it. Blue dotted arrows represent the visual detection and the movement toward the particle of the consumer organisms. Increasing the visual detection allows a better detection by upper trophic levels, potentially leading to the fragmentation of sinking POC into suspended POC due to sloppy feeding. The consumption of the bioluminescent POC by fish can lead to the emission of bioluminescent fecal pellets (repackaging), which can also be produced with non-bioluminescent $\mathrm{POC}$ if the fish gut is already charged with bioluminescent bacteria.

where bacteria are present or on organisms with associated bacteria.

First, vertical samplings in the water column were performed using sterile-bag samplers (Ruby et al., 1980), or later using Niskin bottles (mounted on rosette profilers, Fig. 1c) (Al Ali et al., 2010; Gentile et al., 2009; Kita-Tsukamoto et al., 2006; Martini et al., 2016; Yetinson and Shilo, 1979). This approach is commonly set up in oceanography but relies on relatively small volumes of water (up to $20 \mathrm{~L}$ ). Furthermore, it does not fully capture the heterogeneity of the ecosystem since it provides one discreet sample over restricted time and space. Other instruments dedicated to the acquisition of sediment sampling are the multiple-core samplers, deployed onto the seafloor (Kita-Tsukamoto et al., 2006). For particulate organic carbon and fecal pellets, in order to describe the diversity of associated luminous bacteria, sediment traps (Fig. 1, item e) have been occasionally deployed from the surface down to the deep ocean (Andrews et al., 1984). Using these, fresh luminous material has been collected between 30 and $1900 \mathrm{~m}$ depth.

To study the presence of luminous symbionts in guts and light organs, larger organisms are caught. The most common way to catch deep-sea animals is the deployment of trawls and more generally nets (Fig. 1a-b). They are well-adapted to sample squid (Zamborsky and Nishiguchi, 2011) or fish, like the anglerfish (Freed et al., 2019). One particularity of these methods is that the sampling covers a large section of the water column and combines everything into one catch with a limited precision about depth layers. SCUBA diving is another method to gently select these large animals (Zamborsky and Nishiguchi, 2011). It has also been used to catch fecal pellets and sinking particles (Orzech and Nealson, 1984). Obviously, SCUBA diving has a strong depth limitation (generally above $50 \mathrm{~m}$ depth). It can be more efficient at night for some migrating species and has a restricted sampling size of organisms and number of samples carried back to the ship.

Once environmental samples or material from an organism's light organ have been acquired, the objective is either to describe the taxonomy and diversity of luminous bacteria or to quantify them. To do so, earlier studies have filtered seawater samples through a polycarbonate filter with a pore size of $0.2 \mu \mathrm{m}$ to retain bacteria. The filter is then placed with the bacterial side up on growth medium in Petri dishes (Kita- 
Tsukamoto et al., 2006; Ruby et al., 1980). For symbiotic bacteria, light organs or guts are aseptically dissected shortly after death, and the content is homogenized before culture or microscopic observations (Dunlap, 1984). After hours of incubation, the total colony-forming units is observed; the luminous colonies can, then, be enumerated and selected for taxonomic investigation.

Further investigations of symbiotic associations, in relation to the surrounding environment, would require a reliable taxonomy of luminous bacteria and robust knowledge on species-specific symbiotic associations. As an example, Photobacterium phosphoreum was thought to be the specific symbiont of light organs of numerous deep-sea fish (Hendrie et al., 1970; Ruby et al., 1980; Ruby and Morin, 1978), before a phylogenetic analysis showed distinct evolutionary lineages in the P. phosphoreum clade according to the colonized habitat. This resolution revealed that all the $P$. phosphoreum symbionts isolated from light organs should actually be identified as P. kishitanii (Ast and Dunlap, 2005).

\subsection{Future strategy to quantify the role of bioluminescence in the biological carbon cycle}

Since these first investigations on luminous bacteria in symbioses or in the environment, there has been a huge improvement in technology and molecular-biology techniques. To better evaluate the role of bioluminescence and luminous bacteria in the biological carbon pump, further studies have to follow an efficient strategy. Such a strategy will focus on quantifying this functional trait and how it impacts the transfer of organic carbon between trophic levels, as well as its sequestration into the deep ocean. This approach can be divided into several key points: (1) the assessment of the global importance of bioluminescence in the oceans, (2) the pursuit of investigations about the quantification and diversity of luminous bacteria and their variability between ecosystems (free-living in the water column, on sinking particles and fecal pellets, or in sediments), (3) the quantification of luminous bacterial release into the surrounding environment and the potential impact of diel vertical migration of zooplankton and fish, and (4) the quantification of the transfer rate of bacteria attached to glowing particles to zooplankton and the quantification of the effects on organic matter decomposition, sinking rate and fluxes, in comparison to non-glowing particles. In this review, future perspectives to allow major advances on these specific key points are proposed based on recently developed technologies.

\subsubsection{Assessment of the global importance of bioluminescence in the oceans}

In order to establish the global importance of light emitted by organisms, which include glowing bacteria, quantitative surveys are needed at large spatial scales including geographical variability and depth. Current existing fixed platforms (including observatories), oceanographic vessels, remotely operated and autonomous underwater vehicles (AUVs), and gliders (Fig. 1f, i) have considerably increased our knowledge of marine ecosystems and their spatial variability. For temporal scales, in the last decades, the multiplication of long-term observatories such as Ocean Network Canada $(\mathrm{ONC})$, the Ocean Observatories Initiative (OOI), the station ALOHA, the European Multidisciplinary Seafloor and water column Observatory (EMSO ERIC), or the international Biogeochemical Argo program has increased global ocean observations at long timescales (more than 10 years) and high sampling frequency. To quantitatively record bioluminescence emissions, some instruments are commercially available, or have been adapted from existing sensors. Bathyphotometers (Fig. 1d), a system pumping water into a closed chamber and measuring the emission of light by a photomultiplier, are the most commonly used (Herren et al., 2005) and have already been implemented on AUVs (Berge et al., 2012; Messié et al., 2019; Moline et al., 2009) and other vertical profilers (Cronin et al., 2016). Other approaches have been developed unexpectedly from astrophysics telescopes (Fig. 1, item h) using photomultipliers with a very high sensitivity to photons embedded into optical modules. These instruments have been proven to be efficient to detect bioluminescence in deep-sea environments and over long-time surveys (Aguzzi et al., 2017; Martini et al., 2014; Tamburini et al., 2013a). Another example of quantitative records of photon counts is the equipment of bio-samplers, such as elephant seals, with a small, autonomous tag recording environmental light and bioluminescence (Fig. 1g). These tags have been shown to be a great improvement in highlighting ecological functions such as predator-prey relationships and could inform on the role of bioluminescent prey for seals (Goulet et al., 2020; Vacquié-Garcia et al., 2012). The technological development of high-sensitivity cameras has opened another path for bioluminescence exploration. Low-light cameras have been used to record in situ light patterns (Maxmen, 2018; Phillips et al., 2016) and implemented on remotely operated vehicles for direct in situ observations of sinking particles, or marine luminescent creatures (Fig. 1i-j)

Theoretically, both bacterial light, glowing continuously, and eukaryotic light, emitted as flashes, could be detected. All of these instruments, with the capability to record surrounding or mechanically stimulated light, have been extensively developed or adapted within the last 10 years. Their future implementation on multiple observatories and vehicles will definitely increase our knowledge on the global importance of bioluminescence in the oceans. Long-time surveys could elucidate observed extreme events, such as the bacterial abundance in water-mass movements and sediment resuspension (Durrieu de Madron et al., 2017) or the frequency of milky seas (Lapota et al., 1988; Miller et al., 2005) due to luminous bacteria. Over space, profilers will provide information about the role of bioluminescence in diel vertical migrations of zooplankton and fish. However, the future chal- 
lenge is that the deployment of these instruments has to be done in parallel with data analysis. Acquisition of quantitative signal will induce the discrimination of different groups of organisms including bacteria, and, consequently, will require the development of strong statistical methods in signal analysis (Messié et al., 2019).

To go deeper than in situ quantitative observations, samplings are necessary in various ecosystems including marine snow and fecal pellets, water column, sediments, and light organs of fishes and squids.

\subsubsection{Quantification and diversity of luminous bacteria and their variability between ecosystems (free-living in the water column, on sinking particles and fecal pellets, or in sediments)}

Marine snow potentially glows due to luminous microorganisms colonizing these habitats (bacteria, eukaryotes), but there are only a few studies based on limited numbers of samples that have quantified luminous bacteria on marine snow in the dark ocean (Andrews et al., 1984; Orzech and Nealson, 1984). A first step is to establish the extent of glowing particles over depth, to assess if this is a common or marginal phenomenon. This can be done either by direct observation of light or by describing the biodiversity associated with these particles. Particles are difficult to sample due to their fragility. However, vehicles such as remotely operated vehicles are able to collect particles of marine snow at specific depths using suction samplers and bring them back to the surface into biological collectors. Sediment samplers, potentially implemented on benthic rovers, are other instruments used to sample marine snow, fecal pellets and particles. This is already a common tool deployed during oceanographic cruises but samples from sediment traps are generally dedicated to biogeochemistry analyses which involve fixing their content. To assess the activity of luminous bacteria, it will only require keeping this material fresh without fixing reagent in order to observe the light emission. Glowing aggregates can be observed by using low-light cameras and the light measured by photomultipliers. After observations, these samples can be used for multiple biogeochemical analyses including bacterial taxonomic diversity and abundance.

\subsubsection{Quantification of the particle consumption rate and fate of the organic matter between glowing and non-glowing particles}

One current challenge to evaluate the importance of bioluminescence in the biological carbon pump is that, in the literature, there is no quantification of organic-carbon-transfer rates due to glowing bacteria attached to marine snow and fecal pellets to higher trophic levels. Comparisons between glowing particles and non-glowing ones and the fate of the organic matter (i.e., decomposition and particle sinking rate and fluxes), in both cases, are necessary. Few studies related the preferential consumption of luminous bacteria by zooplankton (copepods in Nishida et al., 2002) or fish (Zarubin et al., 2012). It is well-known that marine snow is intensively colonized by bacteria (about $10^{9}$ bacteria per milliliter) (Azam and Long, 2001). Amongst them, luminous bacteria attract zooplankton by emitting light continuously (while flashes of light emitted by zooplankton deter, as mentioned earlier). As an example, Vibrio are important contributors to particulate organic carbon fluxes that have been observed at abyssal depths in the Pacific Ocean (Preston et al., 2019; Boeuf et al., 2019). A better characterization at the species or functional level should highlight the luminous potential related to the presence of such organisms, even at low abundance. In the laboratory, investigations on processes influencing consumption rates of zooplankton on glowing particles can be performed to define the parameters inducing these higher attraction rates. Future studies based on the experimental protocol described by Zarubin et al. (2012) could be improved by including other zooplankton species of importance in the biological carbon pump and multiple bacterial species. In a dark room, under controlled conditions (close to in situ) the attraction rate of glowing (fresh or infected by luminous bacteria) and non-glowing aggregates can be tested on zooplankton (copepods, mysids) as well as higher trophic levels (small fish). The effect of temperature, bacteria species, abundance/diversity of zooplankton communities, glowing/non-glowing particles, light intensity, hydrostatic pressure and other variables can be tested on particle attraction behavior. One main improvement is the capability of low-light cameras to record associated behaviors under the laboratory experiments.

\section{Conclusions}

Light organs and guts of marine animals act as reservoirs for the abundance and persistence of luminous bacteria in the ocean. Additionally to light organs and gut niches, bioluminescent bacteria colonize particles of organic matter, making them glow. Taking into account the powerful attraction of luminescence on fish and zooplankton consumption, luminous bacteria may therefore influence, in different ways, the export and sequestration of biogenic carbon in oceans. In this review, we essentially focused on luminous bacteria. Bioluminescence, although neglected, is known to be one major trait of marine organisms. Therefore, further studies should take into account bioluminescence in other trophic levels and their impact in the biological carbon pump. Finally, a multiinstrumented strategy will definitely increase knowledge on bioluminescence in the biological carbon pump. This strategy can be set up based on both traditional methods and recently developed technology and is promising for the near future. 
Data availability. The data are available upon request.

Author contributions. The following authors were in charge of the initial draft of the corresponding sections: LT: luminous bacteria in light organs and guts and spatial distribution of luminous bacteria; SM: role of luminous bacteria in the biological carbon pump and future strategy. LC and CT supervised the work. LT, SM, LC and $\mathrm{CT}$ wrote, reviewed and edited the final draft.

Competing interests. The authors declare that they have no conflict of interest.

Acknowledgements. We thank Hans Peter Grossart and Jérôme Mallefet for providing helpful comments on an earlier version of this review. We gratefully acknowledge support from CNRS (project EC2CO "HEMERA").

Financial support. This research has been supported by a doctoral grant "Région Sud" and the TANGRAM Architectes agency. The project leading to this publication has received funding from the European FEDER Fund (grant no. 1166-39417).

Review statement. This paper was edited by Carol Robinson and reviewed by two anonymous referees.

\section{References}

Aguzzi, J., Fanelli, E., Ciuffardi, T., Schirone, A., Craig, J., Aiello, S., Ameli, F., Anghinolfi, M., Barbarino, G., Barbarito, E., Beverini, N., Biagi, S., Biagioni, A., Bouhadef, B., Bozza, C., Cacopardo, G., Calamai, M., Calì, C., Capone, A., Caruso, F., Cecchini, S., Ceres, A., Chiarusi, T., Circella, M., Cocimano, R., Coniglione, R., Costa, M., Cuttone, G., D'Amato, C., D'Amico, A., De Bonis, G., De Luca, V., Deniskina, N., Distefano, C., Di Mauro, L. S., Fermani, P., Ferrara, G., Flaminio, V., Fusco, L. A., Garufi, F., Giordano, V., Gmerk, A., Grasso, R., Grella, G., Hugon, C., Imbesi, M., Kulikovskiy, V., Larosa, G., Lattuada, D., Leismüller, K. P., Leonora, E., Litrico, P., Lonardo, A., Longhitano, F., Presti, D. Lo, Maccioni, E., Margiotta, A., Marinelli, A., Martini, A., Masullo, R., Mele, R., Migliozzi, P., Migneco, E., Miraglia, A., Mollo, C. M., Mongelli, M., Morganti, M., Musico, P., Musumeci, M., Nicolau, C. A., Orlando, A., Orzelli, A., Papaleo, R., Pellegrino, C., Pellegriti, M. G., Perrina, C., Piattelli, P., Poma, E., Pulvirenti, S., Raffaelli, F., Randazzo, N., Riccobene, G., Rovelli, A., Sanguineti, M., Sapienza, P., Sciacca, V., Sgura, I., Simeone, F., Sipala, V., Speziale, F., Spitaleri, A., Spurio, M., Stellacci, S. M., Taiuti, M., Terreni, G., Trasatti, L., Trovato, A., Versari, F., Vicini, P., Viola S., and Vivolo, D.: Inertial bioluminescence rhythms at the Capo Passero (KM3NeT-Italia) site, Central Mediterranean Sea, Sci. Rep., 7, 44938, https://doi.org/10.1038/srep44938, 2017.
Al Ali, B., Garel, M., Cuny, P., Miquel, J. C., Toubal, T., Robert, A., and Tamburini, C.: Luminous bacteria in the deep-sea waters near the ANTARES underwater neutrino telescope (Mediterranean Sea), Chem. Ecol., 26, 57-72, https://doi.org/10.1080/02757540903513766, 2010.

Alldredge, A. L. and Silver, M. W.: Characteristics, dynamics and significance of marine snow, Prog. Oceanogr., 20, 41-82, https://doi.org/10.1016/0079-6611(88)90053-5, 1988.

Alldredge, A. L., Granata, T. C., Gotschalk, C. C., and Dickey, T. D.: The physical strength of marine snow and its implications for particle disaggregation in the ocean, Limnol. Oceanogr., 35 , 1415-1428, https://doi.org/10.4319/lo.1990.35.7.1415, 1990.

Andrews, C. C., Karl, D. M., Small, L. F., and Fowler, S. W.: Metabolic activity and bioluminescence of oceanic faecal pellets and sediment trap particles, Nature, 307, 539-541, https://doi.org/10.1038/307539a0,1984.

Ast, J. C. and Dunlap, P. V.: Phylogenetic resolution and habitat specificity of members of the Photobacterium phophoreum species group, Environ. Microbiol., 7, 16411654, https://doi.org/10.1111/j.1462-2920.2005.00859.x, 2005.

Ast, J. C., Cleenwerck, I., Engelbeen, K., Urbanczyk, H., Thompsom, F. L., De Vos, P., and Dunlap, P. V.: Photobacterium kishitanii sp. nov., a luminous marine bacterium symbiotic with deep-sea fishes, Int. J. Syst. Evol. Microbiol., 57, 2073-2078, https://doi.org/10.1099/ijs.0.65153-0, 2007.

Austin, B.: The bacterial microflora of fish, revised, Sci. World J., 6, 931-945, 2006.

Azam, F., and Long, R. A.: Sea snow microcosms, Nature, 414, 495-498, https://doi.org/10.1038/35107174, 2001.

Bagi, A., Riiser, E. S., Molland, H. S., Star, B., Haverkamp, T. H. A., Sydnes, M. O., and Pampanin, D. M.: Gastrointestinal microbial community changes in Atlantic cod (Gadus morhua) exposed to crude oil, BMC Microbiol., 18, 1-14, https://doi.org/10.1186/s12866-018-1171-2, 2018.

Baguet, F. and Marechal, G.: Bioluminescence of bathypelagic fish from the strait of messina, Comp. Biochem. Physiol. Pt. C, 53, 75-82, https://doi.org/10.1016/0306-4492(76)90057-5, 1976.

Baker, L. J., Freed, L. L., Easson, C. G., Lopez, J. V, Sutton, T. T., Nyholm, S. V., and Hendry, T. A.: Diverse deepsea anglerfishes share a genetically reduced luminous symbiont that is acquired from the environment, Elife, 8, 1-21, https://doi.org/10.7554/eLife.47606, 2019.

Barak, M. and Ulitzur, S.: Bioluminescence as an early indication of marine fish spoilage, Eur. J. Appl. Microbiol. Biotechnol., 10, 155-165, https://doi.org/10.1007/BF00504738, 1980.

Bazhenov, S. V., Khrulnova, S. A., Konopleva, M. N., and Manukhov, I. V.: Seasonal changes in luminescent intestinal microflora of the fish inhabiting the Bering and Okhotsk seas, FEMS Microbiol. Lett., 366, 1-13, https://doi.org/10.1093/femsle/fnz040, 2019.

Berge, J., Båtnes, A. S., Johnsen, G., Blackwell, S. M., and Moline, M. A.: Bioluminescence in the high Arctic during the polar night, Mar. Biol., 159, 231-237, https://doi.org/10.1007/s00227011-1798-0, 2012.

Boettcher, K. J. and Ruby, E. G.: Depressed light emission by symbiotic Vibrio fischeri of the sepiolid squid Euprymna scolopes, J. Bacteriol., 172, 3701-3706, https://doi.org/10.1128/jb.172.7.3701-3706.1990, 1990. 
Boettcher, K. J., Ruby, E. G., and McFall-Ngai, M. J.: Bioluminescence in the symbiotic squid Euprymna scolopes is controlled by a daily biological rhythm, J. Comp. Physiol. A, 179, 65-73, https://doi.org/10.1007/BF00193435, 1996.

Boeuf, D., Edwards, B. R., Eppley, J. M., Hu, S. K., Poff, K. E., Romano, A. E., Caron, D., Karl, D., and DeLong, E. F.: Biological composition and microbial dynamics of sinking particulate organic matter at abyssal depths in the oligotrophic open ocean, P. Natl. Acad. Sci. USA, 116, 1182411832, https://doi.org/10.1073/pnas.1903080116, 2019.

Boyd, E. F., Carpenter, M. R., Chowdhury, N., Cohen, A. L., Haines-Menges, B. L., Kalburge, S. S., Kingston, J. ., Lubin, J. B., Ongagna-Yhombi, S. Y., and Whitaker, W. B.: Postgenomic analysis of members of the family Vibrionaceae, Microbiol. Spectr., 3, 1-26, https://doi.org/10.1128/microbiolspec.VE0009-2014, 2015.

Boyd, P. W., Claustre, H., Levy, M., Siegel, D. A., and Weber, T.: Multi-faceted particle pumps drive carbon sequestration in the ocean, Nature, 568, 327-335, https://doi.org/10.1038/s41586019-1098-2, 2019.

Briggs, N., Dall'Olmo, G., and Claustre, H.: Major role of particle fragmentation in regulating biological sequestration of $\mathrm{CO}_{2}$ by the oceans, Science, 367, 791-793, https://doi.org/10.1126/science.aay1790, 2020.

Brown, D., Johnson, F., and Marsland, D.: The pressure, temperature relations of bacterial luminescence, J. Cell. Comp. Physiol., 20, 151-168, 1942.

Buesseler, K. O. and Lampitt, R. S.: Introduction to "Understanding the Ocean's biological pump: Results from VERTIGO”, Deep-Sea Res. Pt. II, 55, 1519-1521, https://doi.org/10.1016/j.dsr2.2008.04.009, 2008.

Claes, J. M. and Mallefet, J.: Bioluminescence of sharks: first synthesis, in: Bioluminescence in Focus - a Collection of Illuminating Essays, edited by: Meyer-Rochow, V. B., Research Signpost, Kerala, India, 51-65, 2009.

Claes, J. M., Aksnes, D. L., and Mallefet, J.: Phantom hunter of the fjords: camouflage by counterillumination in a shark (Etmopterus spinax), J. Exp. Mar. Bio. Ecol., 388, 28-32, https://doi.org/10.1016/j.jembe.2010.03.009, 2010.

Cohen, J. H. and Forward, R. B.: Spectral sensitivity of vertically migrating marine copepods, Biol. Bull., 203, 307-314, https://doi.org/10.2307/1543573, 2002.

Cronin, H. A., Cohen, J. H., Berge, J., Johnsen, G., and Moline, M. A.: Bioluminescence as an ecological factor during high Arctic polar night, Sci. Rep., 6, 1-9, https://doi.org/10.1038/srep36374, 2016.

Dall'Olmo, G., Dingle, J., Polimene, L., Brewin, R. J. W., and Claustre, H.: Substantial energy input to the mesopelagic ecosystem from the seasonal mixed-layer pump, Nat. Geosci., 9, 820823, https://doi.org/10.1038/ngeo2818, 2016.

Davis, M. P., Sparks, J. S., and Smith, W. L.: Repeated and widespread evolution of bioluminescence in marine fishes, PLoS One, 11, e0155154, https://doi.org/10.1371/journal.pone.0155154, 2016.

de Busserolles, F. and Marshall, N. J.: Seeing in the deep-sea: visual adaptations in lanternfishes, Philos. T. R. Soc. B, 372, 20160070 , https://doi.org/10.1098/rstb.2016.0070, 2017.

De La Rocha, C. L. and Passow, U.: Factors influencing the sinking of POC and the efficiency of the bio- logical carbon pump, Deep-Sea Res. Pt. II, 54, 639-658, https://doi.org/10.1016/j.dsr2.2007.01.004, 2007.

DeLong, E. F., Franks, D. G., and Alldredge, A. L.: Phylogenetic diversity of aggregate-attached vs. free-living marine bacterial assemblages, Limnol. Oceanogr., 38, 924-934, https://doi.org/10.4319/lo.1993.38.5.0924, 1993.

DeLuca, M.: Marine luminescent bacteria in the Mediterranean Sea, Thesis Unpubl., 109 pp., 2006.

Deming, J. W., Tabor, P. S., and Colwell, R. R.: Barophilic growth of bacteria from intestinal tracts of deep-sea invertebrates, Microb. Ecol., 7, 85-94, https://doi.org/10.1007/BF02010480, 1981.

Duchatelet, L., Delroisse, J., Flammang, P., Mahillon, J., and Mallefet, J.: Etmopterus spinax, the velvet belly lanternshark, does not use bacterial luminescence, Acta Histochem., 121, 516-521, https://doi.org/10.1016/j.acthis.2019.04.010, 2019.

Dunlap, P. V.: Physiological and morphological state of the symbiotic bacteria from light organs of ponyfish, Biol. Bull., 167, 410-425, https://doi.org/10.2307/1541286, 1984.

Dunlap P.: Biochemistry and Genetics of Bacterial Bioluminescence, in: Bioluminescence: Fundamentals and Applications, in: Biotechnology, Vol. 1, Advances in Biochemical Engineering/Biotechnology 144, edited by: Thouand, G. and Marks, R., Springer, Berlin, Heidelberg, Germany, 37-64, https://doi.org/10.1007/978-3-662-43385-0_2, 2014.

Dunlap, P. V. and Kita-tsukamoto, K.: Luminous bacteria, in: The Prokaryotes: A Handbook on the Biology of Bacteria, Vol. 3, edited by: Dworkin, M., Falkow, S., Rosenberg, E., Schleifer, K. H., and Stackebrandt, E., Springer, New York, NY, USA, 863892, https://doi.org/10.1007/0-387-30742-7_27, 2006.

Dunlap, P. V. and Urbanczyk, H.: Luminous Bacteria, in: The Prokaryotes: prokaryotic Physiology and Biochemistry, edited by: Rosenberg, E., DeLong, E. F., Lory, S., Stackebrandt, E., and Thompson, F., Springer, Berlin, Heidelberg, Germany, 495-528, https://doi.org/10.1007/978-3-642-30141-4_75, 2013.

Dunlap, P. V., Jiemjit, A., Ast, J. C., Pearce, M. M., Marques, R. R., and Lavilla-Pitogo, C. R.: Genomic polymorphism in symbiotic populations of Photobacterium leiognathi, Environ. Microbiol., 6, 145-158, https://doi.org/10.1046/j.1462-2920.2003.00548.x, 2004.

Dunlap, P. V., Ast, J. C., Kimura, S., Fukui, A., Yoshino, T., and Endo, H.: Phylogenetic analysis of host-symbiont specificity and codivergence in bioluminescent symbioses, Cladistics, 23, 507532, https://doi.org/10.1111/j.1096-0031.2007.00157.x, 2007.

Dunlap, P. V., Kojima, Y., Nakamura, S., and Nakamura, M.: Inception of formation and early morphogenesis of the bacterial light organ of the sea urchin cardinalfish, Siphamia versicolor, Mar. Biol., 156, 2011-2020, https://doi.org/10.1007/s00227009-1232-z, 2009.

Durand, L., Zbinden, M., Cueff-Gauchard, V., Duperron, S., Roussel, E. G., Shillito, B., and Cambon-Bonavita, M. A.: Microbial diversity associated with the hydrothermal shrimp Rimicaris exoculata gut and occurrence of a resident microbial community, FEMS Microbiol. Ecol., 71, 291-303, https://doi.org/10.1111/j.1574-6941.2009.00806.x, 2009.

Durrieu de Madron, X., Ramondenc, S., Berline, L., Houpert, L., Bosse, A., Martini, S., Guidi, L., Conan, P., Curtil, C., Delsaut, N., Kunesh, S., Ghiglione, J. F., Marseleix, P., Pujo-Pay, M., Séverin, T., Testor, P., Tamburini, C., and the Antares collaboration: Deep sediment resuspension and thick nepheloid layer 
generation by open-ocean convection, J. Geophys. Res.-Ocean., 122, 2291-2318, https://doi.org/10.1002/2017JC012961, 2017.

Fidopiastis, P. M., Von Boletzky, S., and Ruby, E. G.: A new niche for Vibrio logei, the predominant light organ symbiont of squids in the genus Sepiola, J. Bacteriol., 180, 59-64, 1998.

Fitzgerald, J. M.: Classification of luminous bacteria from the light organ of the Australien pinecone fish, Cleidopus gloriamaris, Achiv. Microbiol., 112, 153-156, https://doi.org/10.1007/BF00429328, 1977.

Frank, T. M., Johnsen, S., and Cronin, T. W.: Light and vision in the deep-sea benthos: II. Vision in deep-sea crustaceans, J. Exp. Biol., 215, 3344-3353, https://doi.org/10.1242/jeb.072033, 2012.

Freed, L. L., Easson, C., Baker, L. M., Fenolio, D., Sutton, T. T., Khan, Y., Blackwelder, P., Hendry, T. A., and Lopez, J. V.: Characterization of the microbiome and bioluminescent symbionts across life stages of Ceratiod anglerfish of the Gulf of Mexico, FEMS Microbiol. Ecol., 95, 1-11, https://doi.org/10.1093/femsec/fiz146, 2019.

Gentile, G., De Luca, M., Denaro, R., La Cono, V., Smedile, F., Scarfi, S., De Domenico, E., De Domenico, M., and Yakimov, M. M.: PCR-based detection of bioluminescent microbial populations in Tyrrhenian Sea, Deep-Sea Res. Pt. II, 56, 763-767, https://doi.org/10.1016/j.dsr2.2008.07.023, 2009.

Givens, C. E., Ransom, B., Bano, N., and Hollibaugh, J. T.: Comparison of the gut microbiomes of 12 bony fish and 3 shark species, Mar. Ecol. Prog. Ser., 518, 209-223, https://doi.org/10.3354/meps11034, 2015.

Goulet, P., Guinet, C., Campagna, C., Campagna, J., Tyack, P. L., and Johnson, M.: Flash and grab?: deep-diving southern elephant seals trigger anti-predator flashes in bioluminescent prey, J. Exp. Biol., 223, 1-11, https://doi.org/10.1242/jeb.222810, 2020.

Grossart, H. P., Dziallas, C., Leunert, F., and Tang, K. W.: Bacteria dispersal by hitchhiking on zooplankton, P. Natl. Acad. Sci. USA, 107, 11959-11964, https://doi.org/10.1073/pnas.1000668107, 2010.

Gruber, D. F., Phillips, B. T., O’Brien, R., Boominathan, V., Veeraraghavan, A., Vasan, G., O’Brien, P., Pieribone, V. A., and Sparks, J. S.: Bioluminescent flashes drive nighttime schooling behavior and synchronized swimming dynamics in flashlight fish, PLoS One, 14, e0219852, https://doi.org/10.1371/journal.pone.0219852, 2019.

Guerrero-Ferreira, R., Gorman, C., Chavez, A. A., Willie, S., and Nishiguchi, M. K.: Characterization of the bacterial diversity in Indo-West Pacific loliginid and sepiolid squid light organs, Microb. Ecol., 65, 214-226, https://doi.org/10.1007/s00248-0120099-6, 2013.

Haddock, S. H. D., Moline, M. A., and Case, J. F.: Bioluminescence in the sea, Annu. Rev. Mar. Sci., 2, 443-493, https://doi.org/10.1146/annurev-marine-120308-081028, 2010.

Haddock, S. H. D., Christianson, L., Francis, W., Martini, S., Powers, M., Dunn, C., Pugh, P., Mills, C., Osborn, K., Seibel, B., Choy, A., Schnitzler, C., Matsumoto, G., Messié, M., Schultz, D., Winnikoff, J., Gasca, R., Browne, W., Johnsen, S., Schlining, K., von Thun, S., Erwin, B., Ryan, J., and Thuesen, E.: Insights into the biodiversity, behavior, and bioluminescence of deep-sea organisms using molecular and maritime technology, Oceanography, 30, 38-47, https://doi.org/10.5670/oceanog.2017.422, 2017.
Hansen, K. and Herring, P. J.: Dual bioluminescent systems in the anglerfish genus Linophryne (Pisces: Ceratioidea), J. Zool., Lond., 182, 103-124, https://doi.org/10.1111/j.14697998.1977.tb04144.x, 1977.

Harvey, E. N. (Ed): A history of luminescence, from the earliest times until 1900, Series Memoirs of the American Philosophical Society, Vol. 44, Philadelphia, PA, USA, https://doi.org/10.5962/bhl.title.14249, 1957.

Hastings, J. W. and Greenberg, E. P.: Quorum sensing: the explanation of a curious phenomenon reveals a common characteristic of bacteria, J. Bacteriol., 181, 2667-2669, 1999.

Haygood, M., Distel, D. L., and Herring, P. J.: Polymerase chain reaction and 16S rRNA gene sequences from the luminous bacterial symbionts of two deep-sea anglerfishes, J. Mar. Biol. Assoc. UK, 72, 149-159, https://doi.org/10.1017/S0025315400048852, 1992.

Haygood, M. G.: Light organ symbioses in fishes, Crit. Rev. Microbiol., 19, 191-216, https://doi.org/10.3109/10408419309113529, 1993.

Haygood, M. G. and Distel, D. L.: Bioluminescent symbionts of flashlight fishes and deep-sea anglerfishes form unique lineages related to the genus Vibrio, Nature, 363, 154-156, https://doi.org/10.1038/363154a0, 1993.

Haygood, M. G., Tebo, B. M., and Nealson, K. H.: Luminous bacteria of a monocentrid fish (Monocentris japonicus) and two anomalopid fishes (Photoblepharon palpebratus and Kryptophanaron alfredi): population sizes and growth within the light organs, and rates of release into the seaw, Mar. Biol., 78, 249-254, https://doi.org/10.1007/BF00393010, 1984.

Hellinger, J., Jägers, P., Donner, M., Sutt, F., Mark, M. D., Senen, B., Tollrian, R., and Herlitze, S.: The flashlight fish Anomalops katoptron uses bioluminescent light to detect prey in the dark, PLoS One, 12, 1-18, https://doi.org/10.1371/journal.pone.0170489, 2017.

Hendrie, M. S., Hodgkiss, W., and Shewan, J. .: The identification, taxonomy and classification of luminous bacteria, J. Gen. Microbiol., 64, 151-169, https://doi.org/10.1099/00221287-64-2-151, 1970.

Hendry, T. A. and Dunlap, P. V.: The uncultured luminous symbiont of Anomalops katoptron (Beryciformes: Anomalopidae) represents a new bacterial genus, Mol. Phylogenet. Evol., 61, 834843, https://doi.org/10.1016/j.ympev.2011.08.006, 2011.

Hendry, T. A. and Dunlap, P. V.: Phylogenetic divergence between the obligate luminous symbionts of flashlight fishes demonstrates specificity of bacteria to host genera, Environ. Microbiol. Rep., 6, 331-338, https://doi.org/10.1111/1758-2229.12135, 2014.

Hendry, T. A., De Wet, J. R., and Dunlap, P. V.: Genomic signatures of obligate host dependence in the luminous bacterial symbiont of a vertebrate, Environ. Microbiol., 16, 2611-2622, https://doi.org/10.1111/1462-2920.12302, 2014.

Hendry, T. A., de Wet, J. R., Dougan, K. E., and Dunlap, P. V.: Genome evolution in the obligate but environmentally active luminous symbionts of flashlight fish, Genome Biol. Evol., 8, 2203-2213, https://doi.org/10.1093/gbe/evw161, 2016.

Hendry, T. A., Freed, L. L., Fader, D., Fenolio, D., Sutton, T. T., and Lopez, J. V.: Ongoing transposon-mediated genome reduction in the luminous bacterial symbionts of deep-sea ceratioid anglerfishes, mBio, 9, 1-16, https://doi.org/10.1128/mBio.0103318,2018 . 
Herren, C. M., Alldredge, A. L., and Case, J. F.: Coastal bioluminescent marine snow: Fine structure of bioluminescence distribution, Cont. Shelf Res., 24, 413-429, https://doi.org/10.1016/j.csr.2003.10.008, 2004.

Herren, C. M., Haddock, S. H. D., Johnson, C., Orrico, C. M., Moline, M. A., and Case, J. F.: A multi-platform bathyphotometer for fine-scale, coastal bioluminescence research, Limnol. Oceanogr. Method., 3, 247-262, https://doi.org/10.4319/lom.2005.3.247, 2005.

Herring, P. J.: Bioluminescence of marine organisms, Nature, 267, 788-793, https://doi.org/10.1038/267788a0, 1977.

Herring, P. J.: Review. Sex with the lights on? A review of bioluminescent sexual dimorphism in the sea, J. Mar. Biol. Assoc. UK, 87, 829-842, https://doi.org/10.1017/S0025315407056433, 2007.

Hickling, C. F.: A new type of luminescence in fishes. II., J. Mar. Biol. Assoc. UK, 14, 495-507, https://doi.org/10.1017/S0025315400009346, 1926.

Johnsen, S., Widder, E. A., and Mobley, C. D.: Propagation and perception of bioluminescence: factors affecting counterillumination as a cryptic strategy, Biol. Bull., 207, 1-16, https://doi.org/10.2307/1543624, 2004.

Johnson, D. G. and Rosenblatt, R. H.: Mechanisms of light organ occlusion in flashlight fishes, family Anomalopidae (Teleostei: Beryciformes), and the evolution of the group, Zool. J. Linn. Soc., 94, 65-96, https://doi.org/10.1111/j.10963642.1988.tb00882.x, 1988.

Jones, B. W. and Nishiguchi, M. K.: Counterillumination in the Hawaiian bobtail squid, Euprymna scolopes Berry (Mollusca: Cephalopoda), Mar. Biol., 144, 1151-1155, https://doi.org/10.1007/s00227-003-1285-3, 2004.

Kaeding, A. J., Ast, J. C., Pearce, M. M., Urbanczyk, H., Kimura, S., Endo, H., Nakamura, M., and Dunlap, P. V.: Phylogenetic diversity and cosymbiosis in the bioluminescent symbioses of Photobacterium mandapamensis, Appl. Environ. Microbiol., 73, 3173-3182, https://doi.org/10.1128/AEM.02212-06, 2007.

Kiørboe, T.: How zooplankton feed: mechanisms, traits and tradeoffs, Biol. Rev., 86, 311-339, https://doi.org/10.1111/j.1469185X.2010.00148.x, 2011.

Kiørboe, T. and Jackson, G. A.: Marine snow, organic solute plumes, and optimal chemosensory behavior of bacteria, Limnol. Oceanogr., 46, 1309-1318, https://doi.org/10.4319/lo.2001.46.6.1309, 2001.

Kita-Tsukamoto, K., Yao, K., Kamiya, A., Yoshizawa, S., Uchiyama, N., Kogure, K., and Wada, M.: Rapid identification of marine bioluminescent bacteria by amplified $16 \mathrm{~S}$ ribosomal RNA gene restriction analysis, FEMS Microbiol. Lett., 256, 298303, https://doi.org/10.1111/j.1574-6968.2006.00129.x, 2006.

Klappenbach, J. A., Dunbar, J. M., and Schmidt, T. M.: rRNA operon copy number reflects ecological strategies of bacteria, Appl. Environ. Microbiol., 66, 1328-1333, https://doi.org/10.1128/AEM.66.4.1328-1333.2000, 2000.

Kremer, N., Philipp, E. E. R., Carpentier, M. C., Brennan, C. A., Kraemer, L., Altura, M. A., Augustin, R., Häsler, R., HeathHeckman, E. A. C., Peyer, S. M., Schwartzman, J., Rader, B. A., Ruby, E. G., Rosenstiel, P., and McFall-Ngai, M. J.: Initial symbiont contact orchestrates host-organ-wide transcriptional changes that prime tissue colonization, Cell Host Microbe, 14, 183-194, https://doi.org/10.1016/j.chom.2013.07.006, 2013.
Land, M. F., Diebel, C. and Marshall, N. J.: Tracking of blue lights by hyperiid amphipods, J. Mar. Biol. Assoc. UK, 75, 71-81, https://doi.org/10.1017/S0025315400015204, 1995.

Lapota, D., Galt, C., Losee, J. R., Huddell, H. D., Orzech, J. K., and Nealson, K. H.: Observations and measurements of planktonic bioluminescence in and around a milky sea, J. Exp. Mar. Bio. Ecol., 119, 55-81, https://doi.org/10.1016/0022-0981(88)901529, 1988.

Lauro, F. M., McDougald, D., Thomas, T., Williams, T. J., Egan, S., Rice, S., DeMaere, M. Z., Ting, L., Ertan, H., Johnson, J., Ferriera, S., Lapidus, A., Anderson, I., Kyrpides, N., Munkf, A. C., Detterg, C., Hang, C. S., Brown, M. V., Robb, F. T., Kjelleberg, S., and Cavicchioli, R.: The genomic basis of trophic strategy in marine bacteria, P. Natl. Acad. Sci. USA, 106, 15527-15533, https://doi.org/10.1073/pnas.0903507106, 2009.

Le Doujet, T., De Santi, C., Klemetsen, T., Hjerde, E., Willassen, N. P., and Haugen, P.: Closely-related Photobacterium strains comprise the majority of bacteria in the gut of migrating Atlantic cod (Gadus morhua), Microbiome, 7, 1-12, https://doi.org/10.1186/s40168-019-0681-y, 2019.

Lee, K. H. and Ruby, E. G.: Effect of the squid host on the abundance and distribution of symbiotic Vibrio fischeri in nature, Appl. Environ. Microbiol., 60, 1565-1571, 1994.

Leisman, G., Cohn, D., and Nealson, K. H.: Bacterial origin of luminescence in marine animals, Science, 208, 1271-1273, https://doi.org/10.1126/science.208.4449.1271,1980.

Lindgren, A. R., Pankey, M. S., Hochberg, F. G., and Oakley, T. H.: A multi-gene phylogeny of Cephalopoda supports convergent morphological evolution in association with multiple habitat shifts in the marine environment, BMC Evol. Biol., 12, 1-15, https://doi.org/10.1186/1471-2148-12-129, 2012.

Liston, J.: The occurrence and distribution of bacterial types on flatfish, J. Gen. Microbiol., 16, 205-216, https://doi.org/10.1099/00221287-16-1-205, 1957.

Makemson, J. C. and Hermosa, G. V.: Luminous bacteria cultured from fish guts in the Gulf of Oman, Luminescence, 14, 161-168, https://doi.org/10.1002/(SICI)15227243(199905/06)14:3<161::AID-BIO538>3.0.CO;2-A, 1999.

Mandel, M. J. and Dunn, A. K.: Impact and influence of the natural Vibrio-squid symbiosis in understanding bacterial-animal interactions, Front. Microbiol., 7, 1-10, https://doi.org/10.3389/fmicb.2016.01982, 2016.

Mark, M. D., Donner, M., Eickelbeck, D., Stepien, J., Nowrousian, M., Kück, U., Paris, F., Hellinger, J., and Herlitze, S.: Visual tuning in the flashlight fish Anomalops katoptron to detect blue, bioluminescent light, PLoS One, 13, 1-19, https://doi.org/10.1371/journal.pone.0198765, 2018.

Marshall J., Kent J., Cronin T. Visual adaptations in crustaceans: Spectral sensitivity in diverse habitats, in: Adaptive Mechanisms in the Ecology of Vision, edited by: Archer, S. N., Djamgoz, M. B. A., Loew, E. R., Partridge, J. C., and Vallerga, S., Springer, Dordrecht, Netherlands, 285-327, https://doi.org/10.1007/97894-017-0619-3_10, 1999.

Martini, S. and Haddock, S. H. D.: Quantification of bioluminescence from the surface to the deep sea demonstrates its predominance as an ecological trait, Sci. Rep., 7, 45750, https://doi.org/10.1038/srep45750, 2017.

Martini, S., Al Ali, B., Garel, M., Nerini, D., Grossi, V., Pacton, M., Casalot, L., Cuny, P., and Tamburini, C.: Effects of hydrostatic 
pressure on growth and luminescence of a piezomesophilic luminous bacteria Photobacterium phosphoreum ANT-2200, PLoS One, 8, e66580, https://doi.org/10.1371/journal.pone.0066580, 2013.

Martini, S., Nerini, D., and Tamburini, C.: Relation between deep bioluminescence and oceanographic variables: a statistical analysis using time-frequency decompositions, Prog. Oceanogr., 127, 117-128, https://doi.org/10.1016/j.pocean.2014.07.003, 2014.

Martini, S., Michotey, V., Casalot, L., Bonin, P., Guasco, S., Garel, M., and Tamburini, C.: Bacteria as part of bioluminescence emission at the deep ANTARES station (North-Western Mediterranean Sea) during a one-year survey, Deep-Sea Res. Pt. I, 116, 33-40, https://doi.org/10.1016/j.dsr.2016.07.014, 2016.

Maxmen, A.: Hidden lives of deep-sea creatures caught on camera, Nature, 561, 296-298, https://doi.org/10.1038/d41586-01806660-2, 2018.

McAllister, D. E.: The significance of ventral bioluminescence in fishes, J. Fish. Res. Board Can., 24, 537-554, https://doi.org/10.1139/f67-047, 1967.

McFall-Ngai, M. J.: The importance of microbes in animal development: lessons from the squid-Vibrio symbiosis, Annu. Rev. Microbiol., 68, 177-194, https://doi.org/10.1146/annurev-micro091313-103654, 2014.

McFall-Ngai, M. J. and Morin, J. G.: Camouflage by disruptive illumination in Leiognathids, a family of shallow-water, bioluminescent fishes, J. Exp. Biol., 156, 119-137, 1991.

McFall-Ngai, M. J. and Ruby, E. G.: Symbiont recognition and subsequent morphogenesis as early events in an animal-bacterial mutualism, Science 254, 1491-1494, 1991.

McFall-Ngai, M. J., Heath-Heckman, E. A. C., Gillette, A. A., Peyer, S. M., and Harvie, E. A.: The secret languages of coevolved symbioses: insights from the Euprymna scolopes-Vibrio fischeri symbiosis, Semin. Immunol., 24, 1-7, https://doi.org/10.1016/j.smim.2011.11.006, 2012.

Messié, M., Shulman, I., Martini, S., and Haddock, S. H. D.: Using fluorescence and bioluminescence sensors to characterize autoand heterotrophic plankton communities, Prog. Oceanogr., 171, 76-92, https://doi.org/10.1016/j.pocean.2018.12.010, 2019.

Meziti, A., Ramette, A., Mente, E., and Kormas, K. A.: Temporal shifts of the Norway lobster (Nephrops norvegicus) gut bacterial communities, FEMS Microbiol. Ecol., 74, 472-484, https://doi.org/10.1111/j.1574-6941.2010.00964.x, 2010.

Michl, S. C., Beyer, M., Ratten, J. M., Hasler, M., LaRoche, J., and Schulz, C.: A diet-change modulates the previously established bacterial gut community in juvenile brown trout (Salmo trutta), Sci. Rep., 9, 2339, https://doi.org/10.1038/s41598-019-38800-7, 2019.

Miller, S. D., Haddock, S. H. D., Elvidge, C. D., and Lee, T. F.: Detection of a bioluminescent milky sea from space, P. Natl. Acad. Sci. USA, 102, 14181-14184, https://doi.org/10.1073/pnas.0507253102, 2005.

Moline, M. A., Blackwell, S. M., Case, J. F., Haddock, S. H. D., Herren, C. M., Orrico, C. M., and Terrill, E.: Bioluminescence to reveal structure and interaction of coastal planktonic communities, Deep-Sea Res. Pt. II, 56, 232-245, https://doi.org/10.1016/j.dsr2.2008.08.002, 2009.

Montgomery, M. K. and McFall-Ngai, M. J.: Late postembryonic development of the symbiotic light organ of Euprymna scolopes (Cephalopoda: Sepiolidae), Biol. Bull., 195, 326-336, https://doi.org/10.2307/1543144, 1998.

Moran, N. A., McLaughlin, H. J., and Sorek, R.: The dynamics and time scale of ongoing genomic erosion in symbiotic bacteria, Science, 323, 379-382, https://doi.org/10.1126/science.1167140, 2009.

Morin, J. G.: Coastal bioluminiscence: patterns and functions, Bull. Mar. Sci., 33, 787-817, 1983.

Munk, O., Hansen, K., and Herring, P. J.: On the development and structure of the escal light organ of some melanocetid deep-sea anglerfishes (Pisces: Ceratioidei), J. Mar. Biol. Assoc. UK, 78 1321, https://doi.org/10.1017/S0025315400044520, 1998.

Musilova, Z., Cortesi, F., Matschiner, M., Davies, W. I. L., Patel, J. S., Stieb, S. M., De Busserolles, F., Malmstrøm, M. Tørresen, O. K., Brown, C. J., Mountford, J. K., Hanel, R., Stenkamp, D. L., Jakobsen, K. S., Carleton, K. L., Jentoft, S., Marshall, J., and Salzburger, W.: Vision using multiple distinct rod opsins in deep-sea fishes, Science, 364, 588-592, https://doi.org/10.1126/science.aav4632, 2019.

Nayak, S. K.: Role of gastrointestinal microbiota in fish, Aquac. Res., 41, 1553-1573, https://doi.org/10.1111/j.13652109.2010.02546.x, 2010.

Nealson, K. H.: Alternative strategies of symbiosis of marine luminous fishes harboring light-emitting bacteria, Trends Biochem. Sci., 4, 105-110, https://doi.org/10.1016/0968-0004(79)903931,1979 .

Nealson, K. H. and Hastings, J. W.: Bacterial bioluminescence: its control and ecological significance, Microbiol. Rev., 43, 496518, https://doi.org/10.1128/MMBR.43.4.496-518.1979, 1979.

Nealson, K. H. and Hastings, J. W.: Quorum sensing on a global scale: massive numbers of bioluminescent bacteria make milky seas, Appl. Environ. Microbiol., 72, 2295-2297, https://doi.org/10.1128/AEM.72.4.2295-2297.2006, 2006.

Nealson, K. H., Platt, T., and Hastings, J. W.: Cellular control of the synthesis and activity of the bacterial luminescent system, $\mathrm{J}$ Bacteriol., 104, 313-322, https://doi.org/10.1128/JB.104.1.313322.1970, 1970.

Nealson, K. H., Haygood, M. G., Tebo, B. M., Roman, M., Miller, E., and McCosker, J. E.: Contribution by symbiotically luminous fishes to the occurrence and bioluminescence of luminous bacteria in seawater, Microb. Ecol., 10, 69-77, https://doi.org/10.1007/BF02011596, 1984.

Nishida, S., Ohtsuka, S., and Parker, A. R.: Functional morphology and food habits of deep-sea copepods of the genus Cephalophanes (Calanoida: Phaennidae): perception of bioluminescence as a strategy for food detection, Mar. Ecol. Prog. Ser., 227, 157171, https://doi.org/10.3354/meps227157, 2002.

Nishiguchi, M. K. and Nair, V. S.: Evolution of symbiosis in the Vibrionaceae: a combined approach using molecules and physiology, Int. J. Syst. Evol. Microbiol., 53, 2019-2026, https://doi.org/10.1099/ijs.0.02792-0, 2003.

Nishiguchi, M. K., Lopez, J. E., and Von Boletzky, S.: Enlightenment of old ideas from new investigations: more questions regarding the evolution of bacteriogenic light organs in squids, Evol. Dev., 23, 1-7, https://doi.org/10.1111/j.1525142X.2004.04009.x, 2004.

Nyholm, S. V. and McFall-Ngai, M. J.: The winnowing: establishing the squid-Vibrio symbiosis, Nat. Rev. Microbiol., 2, 632-642, https://doi.org/10.1038/nrmicro957, 2004. 
Nyholm, S. V., Stabb, E. V., Ruby, E. G., and McFall-Ngai, M. J.: Establishment of an animal-bacterial association: recruiting symbiotic vibrios from the environment, P. Natl. Acad. Sci. USA, 97, 10231-10235, https://doi.org/10.1073/pnas.97.18.10231, 2000.

O'Brien, C. H. and Sizemore, R. K.: Distribution of the luminous bacterium Beneckea harveyi in a semitropical estuarine environment, Appl. Environ. Microbiol., 38, 928-933, 1979.

Ohwada, K., Tabor, P. S., and Colwell, R. R.: Species composition and barotolerance of gut microflora of deepsea benthic macrofauna collected at various depths in the Atlantic Ocean, Appl. Environ. Microbiol., 40, 746-755, https://doi.org/10.1128/AEM.40.4.746-755.1980, 1980.

Orndorff, S. A. and Colwell, R. R: Distribution and identification of luminous bacteria from the Sargasso Sea, Appl. Environ. Microbiol., 39, 983-987, 1980.

Orzech, J. K. and Nealson, K. H.: Bioluminescence of marine snow, its effect on the optical properties on the sea, Int. Soc. Opt. Photonics, 489, 100-106, https://doi.org/10.1117/12.943292, 1984.

Paitio, J., Oba, Y., and Meyer-Rochow, V. B.: Bioluminescent fishes and their eyes, in: Luminescence - an outlook on the phenomena and their applications, InTech, Rijeka, 297-332, 2016.

Pankey, M. S., Foxall, R. L., Ster, I. M., Perry, L. A., Schuster, B. M., Donner, R. A., Coyle, M., Cooper, V. S., and Whistler, C. A.: Host-selected mutations converging on a global regulator drive an adaptive leap towards symbiosis in bacteria, Elife, 6, e24414, https://doi.org/10.7554/eLife.24414, 2017.

Phillips, B. T., Gruber, D. F., Vasan, G., Roman, C. N., Pieribone, V. A., and Sparks, J. S.: Observations of in situ deep-sea marine bioluminescence with a high-speed, highresolution sCMOS camera, Deep-Sea Res. Pt. I, 111, 102-109, https://doi.org/10.1016/j.dsr.2016.02.012, 2016.

Ploug, H. and Grossart, H. P.: Bacterial growth and grazing on diatom aggregates: respiratory carbon turnover as a function of aggregate size and sinking velocity, Limnol. Oceanogr., 45, 14671475, https://doi.org/10.4319/lo.2000.45.7.1467, 2000.

Preston, C. M., Durkin, C. A., and Yamahara, K. M.: DNA metabarcoding reveals organisms contributing to particulate matter flux to abyssal depths in the North East Pacific Ocean, Deep-Sea Res. Pt. II, 173, 104708, https://doi.org/10.1016/j.dsr2.2019.104708, 2019.

Ramaiah, N., and Chandramohan, D.: Ecology and biology of luminous bacteria in the Arabian Sea, in: Oceanography of the Indian Ocean, edited by: Desai, B. N., National Institute of Oceanography, Dona Paula, Goa, India, 11-23, http://drs.nio.org/ drs/handle/2264/2951, 1992.

Ramesh, A. and Venugopalan, V. K.: Luminous microflora associated with the fishes Mugil cephalus and Tachysurus arius, FEMS Microbiol. Lett., 53, 27-34, https://doi.org/10.1016/03781097(88)90009-2, 1988.

Ramesh, A., Loganathan, B. G., and Venugopalan, V. K.: Seasonal distribution of luminous bacteria in the sediments of a tropical estuary, J. Gen. Appl. Microbiol., 35, 363-368, https://doi.org/10.2323/jgam.35.363, 1989.

Ramesh, A., Loganathan, B. G., and Venkateswaran, K.: Ecological dynamics of marine luminous bacteria, J. Basic Microbiol., 30, 689-703, https://doi.org/10.1002/jobm.3620300917, 1990.

Ramesh, C. and Mohanraju, R.: A review on ecology, pathogenicity, genetics and applications of bi- oluminescent bacteria, J. Terr. Mar. Res., 3, 1-32, https://doi.org/10.32610/JTMR.2019.v03i02.001, 2019.

Raymond, J. A. and DeVries, A. L.: Bioluminescence in McMurdo Sound, Antarctica, Limnol. Oceanogr., 21, 599-602, https://doi.org/10.4319/lo.1976.21.4.0599, 1976.

Reichelt, J. L. and Baumann, P.: Taxonomy of the marine, luminous bacteria, Arch. Mikrobiol., 94, 283-330, https://doi.org/10.1007/BF00769027, 1973.

Renwart, M., Delroisse, J., Claes, J. M., and Mallefet, J.: Ultrastructural organization of lantern shark (Etmopterus spinax Linnaeus, 1758) photophores, Zoomorphology, 133, 405-416, https://doi.org/10.1007/s00435-014-0230-y, 2014.

Riiser, E. S., Haverkamp, T. H. A., Borgan, Ø., Jakobsen, K. S., Jentoft, S., and Star, B.: A single vibrionales 16S rRNA oligotype dominates the intestinal microbiome in two geographically separated Atlantic cod populations, Front. Microbiol., 9, 1-14, https://doi.org/10.3389/fmicb.2018.01561, 2018.

Riiser, E. S., Haverkamp, T. H. A., Varadharajan, S., Borgan, Ø., Jakobsen, K. S., Jentoft, S., and Star, B.: Switching on the light: using metagenomic shotgun sequencing to characterize the intestinal microbiome of Atlantic cod, Environ. Microbiol., 21, 2576-2594, https://doi.org/10.1111/1462-2920.14652, 2019.

Romero, J., Ring $\varnothing$, E., and Merrifield, D. L.: The gut microbiota of fish, in: Aquaculture nutrition gut health, probiotics and prebiotics, edited by: Merrifield, D. and Ring $\varnothing$, E., Wiley, Chichester, UK, 75-100, https://doi.org/10.1002/9781118897263.ch4, 2014.

Ruby, E. G.: Lessons from a cooperative, bacterial-animal association: the Vibrio fischeri-Euprymna scolopes light organ symbiosis, Annu. Rev. Microbiol., 50, 591-624, https://doi.org/10.1146/annurev.micro.50.1.591, 1996.

Ruby, E. G. and Asato, L. M.: Growth and flagellation of Vibrio fischeri during initiation of the sepiolid squid light organ symbiosis, Arch. Microbiol., 159, 160-167, https://doi.org/10.1007/BF00250277, 1993.

Ruby, E. G. and Morin, J. G.: Specificity of symbiosis between deep-sea fishes and psychrotrophic luminous bacteria, Deep-Sea Res., 25, 161-167, https://doi.org/10.1016/01466291(78)90003-6, 1978.

Ruby, E. G. and Morin, J. G.: Luminous enteric bacteria of marine fishes: a study of their distribution, densities, and dispersion, Appl. Environ. Microbiol., 38, 406-411, 1979.

Ruby, E. G. and Nealson, K. H.: Seasonal changes in the species composition of luminous bacteria in nearshore seawater, Limnol. Oceanogr., 23, 530-533, https://doi.org/10.4319/lo.1978.23.3.0530, 1978.

Ruby, E. G., Greenberg, E. P., and Hastings, J. W.: Planktonic marine luminous bacteria: species distribution in the water column, Appl. Environ. Microbiol., 39, 302-306, 1980.

Schwartzman, J. A. and Ruby, E. G.: A conserved chemical dialog of mutualism: lessons from squid and vibrio, Microbes Infect., 18, 1-10, https://doi.org/10.1016/j.micinf.2015.08.016, 2016.

Shilo, M. and Yetinson, T.: Physiological characteristics underlying the distribution patterns of luminous bacteria in the Mediterranean Sea and the Gulf of Elat, Appl. Environ. Microbiol., 38, 577-584, 1979.

Siegel, D. A., Buesseler, K. O., Behrenfeld, M. J., Benitez-Nelson, C. R., Boss, E., Brzezinski, M. A., Burd, A., Carlson, C. A., D'Asaro, E. A., Doney, S. C., Perry, M. J., Stanley, R. H. R., and Steinberg, D. K.: Prediction of the export and fate of global ocean 
net primary production: The EXPORTS science plan, Front. Mar. Sci., 3, 1-10, https://doi.org/10.3389/fmars.2016.00022, 2016.

Sparks, J. S., Dunlap, P. V., and Smith, W. L.: Evolution and diversification of a sexually dimorphic luminescent system in ponyfishes (Teleostei: Leiognathidae), including diagnoses for two new genera, Cladistics, 21, 305-327, https://doi.org/10.1111/j.1096-0031.2005.00067.x, 2005.

Stewart, M. M.: The bacterial flora of the slime and intestinal contents of the haddock (Gadus aeglefinus), J. Mar. Biol. Assoc. UK, 18, 35-50, https://doi.org/10.1017/S0025315400051286, 1932.

Sullam, K. E., Essinger, S. D., Lozupone, C. A., O'Connor, M. P., Rosen, G. L., Knight, R., Kilham, S. S., and Russell, J. A.: Environmental and ecological factors that shape the gut bacterial communities of fish: a meta-analysis, Mol. Ecol., 21, 3363-3378, https://doi.org/10.1111/j.1365-294X.2012.05552.x, 2012.

Tamburini, C., Canals, M., Durrieu de Madron, X., Houpert, L., Lefèvre, D., Martini, S., D’Ortenzio, F., Robert, A., Testor, P., Aguilar, J. A., Samarai, I. Al, Albert, A., André, M., Anghinolfi, M., Anton, G., Anvar, S., Ardid, M., Jesus, A. C. A., Astraatmadja, T. L., Aubert, J. J., Baret, B., Basa, S., Bertin, V., Biagi, S., Bigi, A., Bigongiari, C., Bogazzi, C., Bou-Cabo, M., Bouhou, B., Bouwhuis, M. C., Brunner, J., Busto, J., Camarena, F., Capone, A., Cârloganu, C., Carminati, G., Carr, J., Cecchini, S., Charif, Z., Charvis, P., Chiarusi, T., Circella, M., Coniglione, R., Costantini, H., Coyle, P., Curtil, C., Decowski, P., Dekeyser, I., Deschamps, A., Donzaud, C., Dornic, D., Dorosti, H. Q., Drouhin, D., Eberl, T., Emanuele, U., Ernenwein, J. P., Escoffier, S., Fermani, P., Ferri, M., Flaminio, V., Folger, F., Fritsch, U., Fuda, J. L., Galatà, S., Gay, P., Giacomelli, G., Giordano, V., Gómez-González, J. P., Graf, K., Guillard, G., Halladjian, G., Hallewell, G., van Haren, H., Hartman, J., Heijboer, A. J., Hello, Y., Hernández-Rey, J. J., Herold, B., Höß1, J., Hsu, C. C., de Jong, M., Kadler, M., Kalekin, O., Kappes, A., Katz, U., Kavatsyuk, O., Kooijman, P., Kopper, C., Kouchner, A., Kreykenbohm, I., Kulikovskiy, V., Lahmann, R., Lamare, P., Larosa, G., Lattuada, D., Lim, G., Presti, D. Lo, Loehner, H., Loucatos, S., Mangano, S., Marcelin, M., Margiotta, A., Martinez-Mora, J. A., Meli, A., Montaruli, T., Moscoso, L., Motz, H., Neff, M., Nezri, E., Palioselitis, D., Pǎvǎlaş, G. E., Payet, K., Payre, P., Petrovic, J., Piatelli, P., Picot-Clemente, N., Popa, V., Pradier, T., Presani, E., Racca, C., Reed, C., Riccobene, G., Richardt, C., Richter, R., Rivère, C., Roensch, K., Rostovtsev, A., Ruiz-Rivas, J., Rujoju., M., Russo, V. G., Salesa, F., Sánchez-Losa, A., Sapienza, P., Schöck, F., Schuller, J. P., Schussler, F., Shanidze, R., Simeone, F., Spies, A., Spurio, M., Steiiger, J. J., Stolarczyk, T., Taiuti, M, G., Toscano, S., Vallage, B., Van Elewyck, V., Vannoni, G., Vecchi, M., Vernin, P., Wijnker, G., Wilms, J., de Wolf, E., Yepes, H., Zaborov, D., de dios Zornoza, J., and úñiga, J.: Deep-sea bioluminescence blooms after dense water formation at the ocean surface, PLoS One, 8, 1-10, https://doi.org/10.1371/journal.pone.0067523, 2013a.

Tamburini, C., Boutrif, M., Garel, M., Colwell, R. R., and Deming, J. W.: Prokaryotic responses to hydrostatic pressure in the ocean - a review, Environ. Microbiol., 15, 1262-1274, https://doi.org/10.1111/1462-2920.12084, 2013b.

Tanet, L., Tamburini, C., Baumas, C., Garel, M., Simon, G., and Casalot, L.: Bacterial bioluminescence: light emission in Photobacterium phosphoreum is not un- der quorum-sensing control, Front. Microbiol., 10, 1-9, https://doi.org/10.3389/fmicb.2019.00365, 2019.

Tarnecki, A. M., Burgos, F. A., Ray, C. L., and Arias, C. R.: Fish intestinal microbiome: diversity and symbiosis unravelled by metagenomics, J. Appl. Microbiol., 123, 2-17, https:/doi.org/10.1111/jam.13415, 2017.

Tebo, B. M., Scott Linthicum, D., and Nealson, K. H.: Luminous bacteria and light emitting fish: ultrastructure of the symbiosis, BioSystems, 11, 269-280, 1979.

Vacquié-Garcia, J., Royer, F., Dragon, A. C., Viviant, M., Bailleul, F., and Guinet, C.: Foraging in the darkness of the Southern Ocean: influence of bioluminescence on a deep diving predator, PLoS One, 7, 1-11, https://doi.org/10.1371/journal.pone.0043565, 2012.

Verma, S. C. and Miyashiro, T.: Quorum sensing in the squid-Vibrio symbiosis, Int. J. Mol. Sci., 14, 16386-16401, https://doi.org/10.3390/ijms140816386, 2013.

Verner-Jeffreys, D. W., Shields, R. J., Bricknell, I. R., and Birkbeck, T. H.: Changes in the gut-associated microflora during the development of Atlantic halibut (Hippoglossus hippoglossus L.) larvae in three British hatcheries, Aquaculture, 219, 21-42, https://doi.org/10.1016/S0044-8486(02)00348-4, 2003.

Visick, K. L. and Ruby, E. G.: Vibrio fischeri and its host: it takes two to tango, Curr. Opin. Microbiol., 9, 632-638, https://doi.org/10.1016/j.mib.2006.10.001, 2006.

Visick, K. L., Foster, J., Doino, J., McFall-Ngai, M., and Ruby, E. G.: Vibrio fischeri lux genes play an important role in colonization and development of the host light organ, J. Bacteriol., 182, 4578-4586, https://doi.org/10.1128/JB.182.16.4578-4586.2000, 2000.

Wada, M., Yamamoto, I., Nakagawa, M., Kogure, K., and Ohwada, K.: Photon emission from dead marine organisms monitored using a video recording system, J. Mar. Biotechnol., 2, 205-209, 1995.

Wang, A. R., Ran, C., Ring $\varnothing$, E., and Zhou, Z. G.: Progress in fish gastrointestinal microbiota research, Rev. Aquac., 10, 626-640, https://doi.org/10.1111/raq.12191, 2018.

Ward, N. L., Steven, B., Penn, K., Methé, B. A., and Detrich, W. H.: Characterization of the intestinal microbiota of two Antarctic notothenioid fish species, Extremophiles, 13, 679-685, https://doi.org/10.1007/s00792-009-0252-4, 2009.

Warner, J. A., Latz, M. I., and Case, J. F.: Cryptic bioluminescence in a midwater shrimp, Science, 203, 1109-1110, https://doi.org/10.1126/science.203.4385.1109, 1979.

Warrant, E. J. and Locket, N. A.: Vision in the deep sea, Biol. Rev., 79, 671-712, https://doi.org/10.1017/s1464793103006420, 2004.

Widder, E. A.: Bioluminescence and the pelagic visual environment, Mar. Freshw. Behav. Physiol., 35, 1-26, https://doi.org/10.1080/10236240290025581, 2002.

Widder, E. A.: Bioluminescence in the ocean: origins of biological, chemical, and ecological diversity, Science, 328, 704-708, https://doi.org/10.1126/science.1174269, 2010.

Yetinson, T. and Shilo, M.: Seasonal and geographic distribution of luminous bacteria in the Eastern Mediterranean Sea and the Gulf of Elat, Appl. Environ. Microbiol., 37, 1230-1238, https://doi.org/10.1016/0198-0254(79)90940-3, 1979.

Yooseph, S., Nealson, K. H., Rusch, D. B., McCrow, J. P., Dupont, C. L., Kim, M., Johnson, J., Montgomery, R., Ferriera, S., Bee- 
son, K., Williamson, S. J., Tovchigrechko, A., Allen, A. E., Zeigler, L. A., Sutton, G., Eisenstadt, E., Rogers, Y. H., Friedman, R., Frazier, M., and Venter, J. C.: Genomic and functional adaptation in surface ocean planktonic prokaryotes, Nature, 468, 60-66, https://doi.org/10.1038/nature09530, 2010.

Zamborsky, D. J. and Nishiguchi, M. K.: Phylogeographical patterns among mediterranean sepiolid squids and their Vibrio symbionts: environment drives specificity among sympatric species, Appl. Environ. Microbiol., 77, 642-649, https://doi.org/10.1128/AEM.02105-10, 2011.

Zarubin, M., Belkin, S., Ionescu, M., and Genin, A.: From the cover: bacterial bioluminescence as a lure for marine zooplankton and fish, P. Natl. Acad. Sci. USA, 109, 853-857, https://doi.org/10.1073/pnas.1116683109, 2012.
Zhang, S. Da, Santini, C. L., Zhang, W. J., Barbe, V., Mangenot, S., Guyomar, C., Garel, M., Chen, H. T., Li, X. G., Yin, Q. J., Zhao, Y., Armengaud, J., Gaillard, J. C., Martini, S., Pradel, N., Vidaud, C., Alberto, F., Médigue, C., C., Tamburini, C., and $\mathrm{Wu}, \mathrm{L}$. F.: Genomic and physiological analysis reveals versatile metabolic capacity of deep-sea Photobacterium phosphoreum ANT-2200, Extremophiles, 20, 301-310, https://doi.org/10.1007/s00792-016-0822-1, 2016.

Zhou, Z., Yao, B., Romero, J., Waines, P., Ring $\varnothing$, E., Emery, M., Liles, M. R., and Merrifield, D. L.: Methodological approaches used to assess fish gastrointestinal communities, in: Aquaculture nutrition gut health, probiotics and prebiotics, edited by: Merrifield, D. and Ring $\varnothing$, E., Wiley, Chichester, UK, 75-100, https://doi.org/10.1002/9781118897263.ch5, 2014.

ZoBell, C. E. and Morita, R. Y.: Barophilic bacteria in some deep sea sediments, J. Bacteriol., 73, 563-8, 1957. 